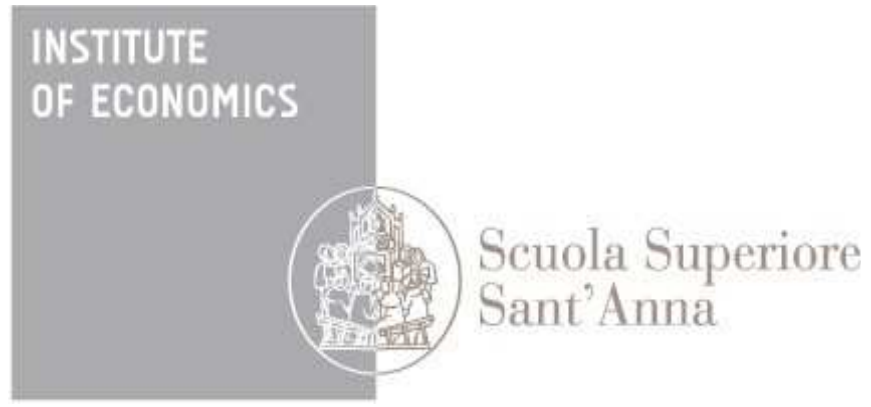

LEM | Laboratory of Economics and Management Institute of Economics

Scuola Superiore Sant'Anna

Piazza Martiri della Libertà, 33 - 56127 Pisa, Italy ph. +3905088.33 .43$

institute.economics@sssup.it

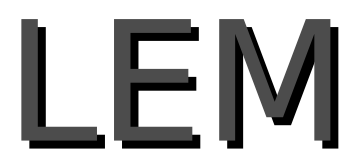

Working Paper Series

\title{
Macroprudential Policy: a Blessing or a Curse?
}

\author{
Lilit Popoyan ${ }^{\circ}$
}

'Institute of Economics, Scuola Superiore Sant'Anna, Pisa, Italy

\section{6/21




\title{
Macroprudential Policy: a Blessing or a Curse?
}

\author{
Lilit Popoyan*
}

\begin{abstract}
After the destructive impact of the global financial crisis of 2008, many believe that pre-crisis financial market regulation did not take the "big picture" of the system sufficiently into account and, subsequently, financial supervision mainly "missed the forest for the trees". As a result, the need for macroprudential aspects of regulation emerged, which has recently become the focal point of many policy debates. This has also led to intense discussion on the contours of monetary policy after the post-crisis "new normal". Here, I review recent progress in empirical and theoretical research on the effectiveness of macroprudential tools, as well as the current state of the debate, in order to extract common policy conclusions. The work highlights that, despite the achievements in the literature, the current experience and knowledge of how macroprudential instruments work, their calibration, and the mechanisms through which they interact with each other and with monetary policy are rather limited and conflicting. Moreover, I critically survey and note the current challenges faced by macroprudential regulation in creating stable, yet efficient financial systems. At the same time, I emphasize the importance of accepting that many risks may remain, requiring that we proceed prudently and develop better plans for future crises.
\end{abstract}

Keywords: macroprudential policy; Basel III regulation; capital adequacy ratio; countercyclical capital buffer; leverage requirement; systemic risk; crisis management; financial stability.

JEL Classification Numbers: E02, E32, E52, E58, E6, G01, G21, G28.

${ }^{*}$ Institute of Economics (LEM), Scuola Superiore Sant'Anna, Pisa (Italy); Piazza Martiri della Libertá 33-I56127 Pisa (Italy) ; E-mail address: 1.popoyan@sssup.it. 


\section{Introduction}

The turmoil of the recent financial crisis and the economic downswing that followed has raised a fundamental debate on the need to re-orient the financial regulatory framework for fostering financial stability through better regulation and supervision of financial markets (Blanchard et al. 2010, Yellen 2011, Duca et al. 2010). The growing complexity had made it difficult for policymakers to assess the potential spillovers between the financial institutions and markets because banks were heavily interconnected and highly leveraged, financial intermediation had shifted to the shadow banking sector, both funding and market liquidity risks were higher than expected, and there was a critical absence of effective mechanisms to deal with systemically important financial institutions. In terms of policy, crisis of 2008 has demonstrated that neither traditional financial regulation, usually called microprudential, nor price stability are sufficient to guarantee the safety and soundness of the overall financial system. Moreover, it has revealed that the "originate-to-distribute" model of bank lending needs to be strengthened and more regulated (Berndt \& Gupta 2009, Purnanandam 2011). The policy debate is mainly concentrated on taming the procyclical nature of the capital requirement in Basel II (Andersen 2011, Borio \& Zhu 2012, Angeloni \& Faia 2013), constraining agents' incentives to build-up excessive leverage (Dell'Ariccia et al. 2013, Valencia 2014) and reducing liquidity (Chadha \& Corrado 2012, van den End \& Kruidhof 2013) and maturity mismatch (Brinkhoff et al. 2013, Brunnermeier et al. 2014) risks.

The crisis has fostered a recognition that systemic risks can grow under the surface of apparent economic tranquility (Anand et al. 2012, Battiston et al. 2012a, Acemoglu et al. 2015). Therefore, financial stability should not emerge as a natural by-product of an appropriate macroeconomic policy mix. Rather, achieving the objective of financial stability requires dedicated macroprudential policy. Moreover, to guarantee macroeconomic stability, monetary policy may adopt financial stability as an additional objective. However, a new objective requires new instruments that are able to target specific sources of financial imbalances, where monetary policy is "too blunt a tool":

"[... the contours of the macroeconomic policy of the future are only slowly coming into focus. From macroeconomic to financial stability, policy makers have realized that they have to watch many targets. They have also realized that they have potentially many more instruments at their disposal, from macroprudential tools to unconventional monetary policy. But how to map instruments to targets remains very much a work in progress. [...]"(Olivier Blanchard, "Rethinking Macro Policy II: First Steps and Early Lessons", Washington, DC, April 16-17, 2013)

The economic collapse has catalyzed the attention of policymakers on the very nature of financial crises, stimulating a fresh wave of research. This research focuses on the need for a new macro-based financial regulation regime, aimed at defining and measuring systemic risk and creating mechanisms to constrain the mitigation of the latter:

"[... three "must haves" microprudential regulation, supervision, and resolution are necessary, but as the crisis has made clear, they are not sufficient to rein in systemic risks. They must be complemented by an overarching macroprudential framework 
and a set of new tools to complete the toolkit to address systemic risks. [...]"(Jos Vials, Rebuilding Financial Markets, Frankfurt, 9-11 November 2010)

The Basel III financial regulatory accord emerged as a result:

"[...]Basel III represents a fundamental strengthening in some cases, a radical overhaul of global capital standards. Together with the introduction of global liquidity standards, the new capital standards deliver on the core of the global financial reform agenda,[...]" ( Jaime Caruana, "Basel III: towards a safer financial system", Madrid, 15 September 2010)

Despite the progress in policy design, the implementation of the macroprudential policy framework is still in an embryonic stage. However, the policy perimeter and discussions are quite extensive. The policy discussion focuses particularly on the implementation and effectiveness of macroprudential instruments, as well as on their relationship with monetary policy and their impact on macroeconomic performance:

"[...IIt was clear that the two standard tools, fiscal and monetary policy, were not the right ones to deal with financial imbalances and risks. The question then was: is macroprudential policy going to be the third leg of macroeconomic policy, or just a crutch to help the first two?[...]"(Olivier Blanchard, IMF Direct blog, 29 April 2013)

I focus on and provide an overview of macroprudential policy line research. Here, I emphasize the macroeconomic perspective and the implications of macroprudential tools, as well as their limits. I also underline the question of conflicts and trade-offs between the monetary policy and macroprudential policy. By drawing parallels with research literature on macroprudential policy effects and monetary policy, this study aims to contribute to the evolving debate. The objectives are to lay out key concepts and an agreed terminology, and to assess existing practices, the state of knowledge, and priorities for future work in the macroprudential policy framework.

I find that the recent progress in empirical and theoretical literature both on the impact of macroprudential policy, and on the interaction schemes between macroprudential and monetary policies, have still provided limited guidance for policy implementation. Nevertheless, different approaches in literature have come to common conclusions on "leaning-against-the-wind" coordination between monetary and macroprudential policies (see Angeloni \& Faia 2013, Quint \& Rabanal 2014, Krug 2015, Popoyan et al. 2015) and stabilizing gains from asset-based tools and contercyclical capital requirements (see DellAriccia et al. 2012, IMF 2013, Aiyar et al. 2014, Bridges et al. 2014, Cerutti et al. 2015). However, the new post-crisis macroprudential policy remains more "microprudential", and a focus on system-wide risk characteristics is lacking. Furthermore, owing to the overlapping transmission mechanisms of monetary and macroprudential policies, how to combine these two policies is a hotly debated question. While following real-world developments, two institutional models have emerged: (i) macroprudential policy is assigned to a board, conducted separately from monetary policy; and (ii) macroprudential policy is assigned to a central bank and conducted together with monetary policy. Finally, partially because of a scarcity in historical, empirical, and theoretical experience in dealing with macroprudential instruments, and partially because of the difficulty in measuring systemic risks 
and an underdeveloped analytical framework to assess the transmission channels of those risks, financial crises are an objective reality.

The remainder of this paper is structured as follows. Section 2 provides guidance on the definition of macroprudential policy, its main objective, the classifications of macroprudential tools, and discusses the coexistence of monetary and macroprudential policy. Section 3 explores the recent literature on macroprudential policy impacts, its efficiency and interaction with other policy groups. Section 4 discusses the pros and cons of the ability of macroprudential policy to contribute to crisis management and to prevent future financial turmoil. Finally, Section 5 concludes by discussing the focal points of the paper.

\section{Macroprudential Policy: Scope, Tools and Relationship with Monetary Policy}

One of the heritages of the global financial crisis of 2008 and its aftermath is a painful reminder of the polyhedral macro-financial linkages and interactions. The first common cause emphasized in the literature on the recent turmoil is the occurrence of a rapid financial expansion, or credit boom (see Koo 2011). As shown in Figure 1, the pre-crises period (until the first quarter of 2008) was characterized by rapid credit expansion and real GDP growth. However, during the crisis, both showed a noticeable drop. While booms do not always cause crises, they do make them more likely to occur (DellAriccia et al. 2012, Jordà et al. 2015, Taylor 2015). Moreover, credit booms are mostly associated with high leverage and post-shock rapid de-leveraging, which makes them more dangerous and more painful (see Figure 2). In Figure 2 the evolution of the leverage level for the United States and the euro area (2008 and 2011, first quarter) are illustrated. The map captures the high leverage in both regions and the post-crisis de-leveraging. These causes of a crisis have led to a shift toward a macroprudential (system-wide) approach to financial supervision and regulation (see in Bernanke 2008, Blanchard et al. 2010, 2013). Moreover, it brought to an evolving debate about the interplay between macroprudential and monetary policies in practice.

\subsection{Macroprudential Policy Toolkit}

After the crisis, the need for macroprudential regulation was obvious to policymakers, but there was no precise definition of macroprudential policy until 2011. The agreement on "Macroprudential policy frameworks", produced jointly by the Financial Stability Board (FSB), the International Monetary Fund (IMF), and the Bank for International Settlements (BIS) in February 2011, managed to establish a common language for policymakers. The agreement defined macroprudential policy as "a policy that uses primarily prudential tools to limit systemic or system-wide financial risk, thereby limiting the incidence of disruptions in the provision of key financial services that can have serious consequences for the real economy by (i) dampening the build-up of financial imbalances and building defenses that contain the speed and sharpness of subsequent downswings and their effects on the economy; and (ii) identifying and addressing common exposures, risk concentrations, linkages, and interdependencies that are sources of contagion and spillover risks that may jeopardize the functioning of the system as a whole" (see 
(a) Real GDP growth

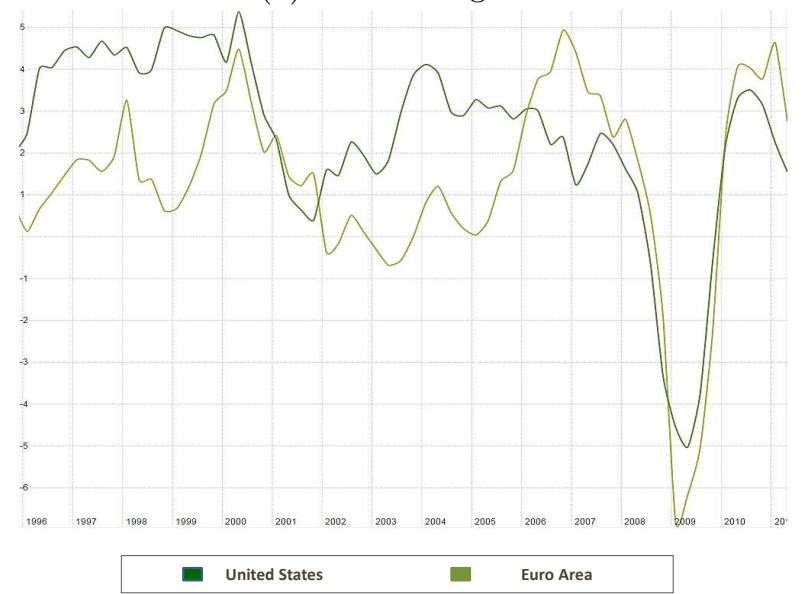

(b) Real credit growth

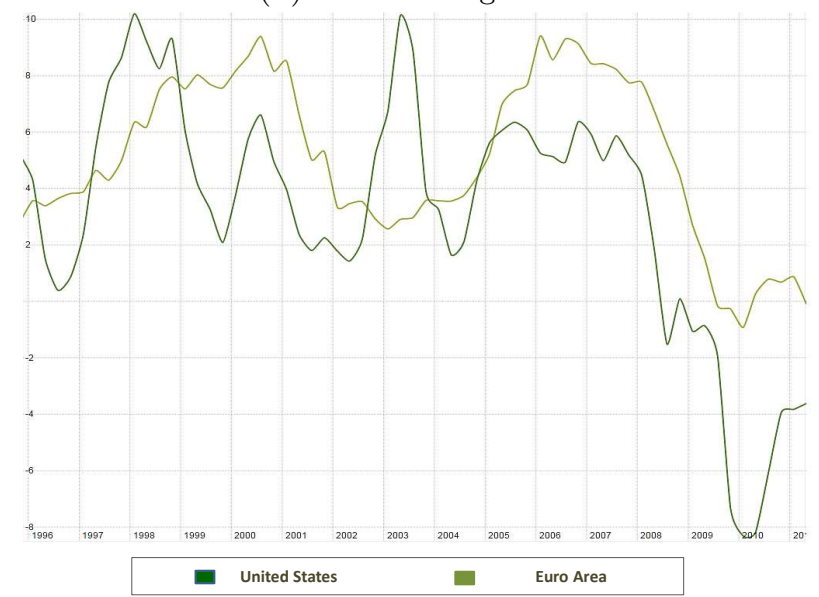

Note: The dataset is based upon that in Sarlin $\&$ Peltonen (2013), of which further details are available in Sarlin (2014), and which to a large extent descends from Duca \& Peltonen (2013).

Figure 1: Real GDP and credit growth in United States and euro area in 1996-2012

the official document in FSB 2011a). A general objective of Basel III macroprudential reform is to design and implement a policy that will prevent cross-institution or cross-market knock-on effects that can magnify problems. A second objective is to reduce the likelihood that the system as a whole will experience such knock-on effects. Hence, effective macroprudential policy could contain risks ex-ante and help build buffers to absorb shocks ex-post. Hence, the final objective of macroprudential policy is to contribute to the safety, soundness, and stability of the financial system as a whole. This combines strengthening the resilience of the financial system and decreasing the build-up of systemic vulnerabilities.

Pre-crisis microprudential supervision contributed to financial stability primarily in terms of the safety and soundness of individual financial institutions only. ${ }^{1}$ However, this ignored the aggregate negative impact of individual decisions on the financial system as a whole. In turn, macroprudential policy tries to fix this drawback by addressing two dimensions of the systemic risk. First, it aims to identify and control the evolution of systemic risk - the time dimension ("time-varying" or "cyclical" risk) and, second, it tries to detect how risks are allocated within the financial system - the cross-sectional dimension ("cross-sectional" or "structural" risk). ${ }^{2}$

The time dimension catches the collective tendency of economic agents to increase their risk exposures during the expansionary phases of credit cycles, and to rapidly unwind risk during the contractionary phases, due to the overlay risk-aversion. This procyclicality intensifies in credit and liquidity cycles induced by excessive leverage and excessive maturity mismatches in financial institutions. During an expansion, the procyclicality described above makes the financial system more sensitive to both endogenous and exogenous shocks. Consequently, the build-up in aggregate risk increases the probability of financial distress.

\footnotetext{
${ }^{1}$ I consider microprudential instruments as those that focus on the health of individual financial institutions, and macroprudential policy tools as those that address risks to the financial system as a whole (for a definition, see Osinski et al. 2013).

${ }^{2}$ The classification is consistent with Kohn (2010), Bank of England (2011), FSB (2011a), IMF (2011). For other classifications, see Hoogduin (2010), IMF (2011), Bank of England (2011), ECB (2014), ECB Heads of Research (2014).
} 
(a) Leverage in US and euro area 2008/1

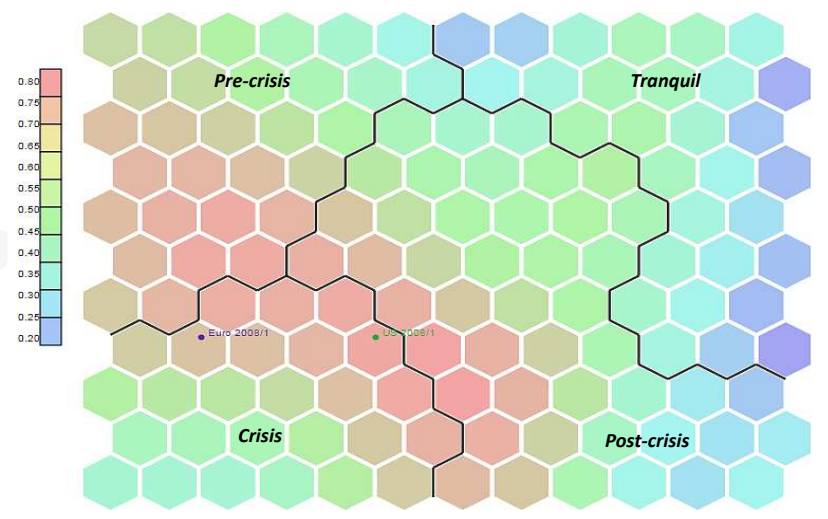

(b) Leverage in US and euro area 2011/1

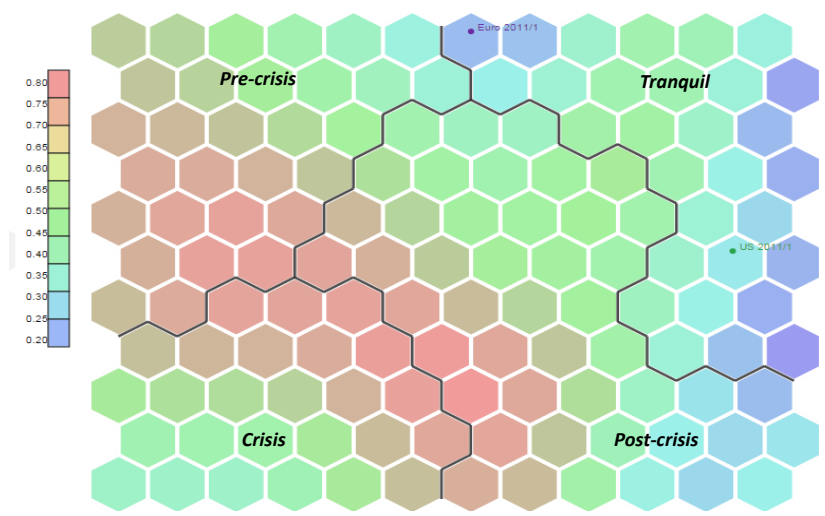

Note: The figure displays the two-dimensional representation of leverage space. The lines that separate the map into four parts are based on the distribution of the four underlying financial stability states. In the left figure, the data for both the US and the euro area represent the 2002-2011, first quarter(see Sarlin E Peltonen (2013)).

Figure 2: Leverage in United States and euro area in 2008/1 and 2011/1

In contrast, the cross-sectional dimension identifies the distribution of risk at a given point in time in order to contain domino effects. It focuses mainly on the high interconnectedness of financial institutions, working through the direct balance sheet channel (e.g., cross exposures) or through indirect linkages.

The potential macroprudential policy armory is quite wide, with some of the tools being used even before the recent financial turmoil. ${ }^{3}$ Table 1 classifies these in a matrix form (see Claessens et al. 2013, Claessens 2014). Vertically, the matrix covers the policies and their goals. Horizontally, the matrix shows the intermediate targets (e.g., changes in credit, leverage, asset prices, interconnections, etc.) and methods.

Considering the goals of different types of macroprudential policies, it is practical to categorize them into three groups (the rows in Table 1). The first two groups try to reduce the probability of the occurrence and consequences of financial risks by respectively dampening the expansionary phase of the credit cycle or strengthening the resilience of the financial institutions during the pre-contractionary and contractionary phases of the cycle. The third group targets the risks arising from the direct and indirect interconnectedness of financial institutions. Along the horizontal axis, the table covers five sets of tools: a) quantitative restrictions on borrowers, instruments, or activities; b) capital and provisioning requirements; c) other quantitative restrictions on financial institutions' balance sheets; d) taxation/levies on activities or balance sheet composition; and e) other, more institutional-oriented measures, such as accounting changes, changes to compensation, and so on. Except for the tools in a), which aims to affect the demand for financing, the other groups of tools affect the supply side of financing. The first four sets of macroprudential measures (a-d) are meant to be time, institution, or state varying, while the fifth is more structural.

\footnotetext{
${ }^{3}$ A rule-based dynamic provisioning has been implemented in Spain since 2000 (see more in Saurina 2009, Jiménez et al. 2012), and caps on LTV and LTI ratios in Korea were introduced in 2002 and 2005, respectively (see in Igan \& Kang 2011).
} 
Policy Tools

\begin{tabular}{|c|c|c|c|c|c|}
\hline \multicolumn{6}{|c|}{ Policy Tools } \\
\hline & $\begin{array}{l}\text { Restrictions on } \\
\text { financial sector } \\
\text { balance sheet }\end{array}$ & $\begin{array}{l}\text { Capital requirements } \\
\text { provisioning, surcharges }\end{array}$ & $\begin{array}{l}\text { Restrictions on } \\
\text { borrower }\end{array}$ & Taxation, levies & Other \\
\hline $\begin{array}{l}\text { Expansionary } \\
\text { phase }\end{array}$ & $\begin{array}{l}\text { Caps/limits on: } \\
\text { - credit growth } \\
\text {-foreign lending } \\
\text { Reserve requirements }\end{array}$ & $\begin{array}{l}\text { Countercyclical capital } \\
\text { requirement } \\
\text { Leverage restrictions } \\
\text { Dynamic provisioning }\end{array}$ & $\begin{array}{l}\text { Caps/limits on: } \\
\text {-debt-to-income } \\
\text {-loan-to-income } \\
\text {-loan-to-value }\end{array}$ & $\begin{array}{l}\text { Levy/tax on specific } \\
\text { assets and/or } \\
\text { core liabilities }\end{array}$ & $\begin{array}{l}\text {-Accounting (e.g., } \\
\text { varying rules on market } \\
\text { to market) } \\
\text {-Changes to } \\
\text { compensation, market } \\
\text { discipline, governance }\end{array}$ \\
\hline $\begin{array}{l}\text { Contractionary } \\
\text { phase }\end{array}$ & $\begin{array}{l}\text { Liquidity limits } \\
\text {-liquidity coverage } \\
\text { ratio (LCR) } \\
\text {-net stable } \\
\text { funding ratio(NSFR) }\end{array}$ & $\begin{array}{l}\text { Countercyclical capital } \\
\text { requirement } \\
\text { Dynamic provisioning }\end{array}$ & $\begin{array}{l}\text {-Adjustment to } \\
\text { specific loan-loss } \\
\text { provisioning, } \\
\text { margins, hair-cuts }\end{array}$ & $\begin{array}{l}\text { Levy/tax (e.g., on } \\
\text { non-core liabilities) }\end{array}$ & $\begin{array}{l}\text {-Standardized } \\
\text { products } \\
\text {-OTC vs. on exchange } \\
\text {-Safety net (Central } \\
\text { Bank/Treasury } \\
\text { liquidity, fiscal } \\
\text { support) }\end{array}$ \\
\hline $\begin{array}{l}\text { Contagion from } \\
\text { SIFIs or networks }\end{array}$ & $\begin{array}{l}\text { Institution- specific } \\
\text { limits on (bilateral) } \\
\text { financial exposures, }\end{array}$ & $\begin{array}{l}\text { Capital surcharges } \\
\text { linked to systemic } \\
\text { risk }\end{array}$ & $\begin{array}{l}\text { Varying restrictions } \\
\text { on asset composition, } \\
\text { activities }\end{array}$ & $\begin{array}{l}\text { Tax/levy varying by } \\
\text { externality (size, } \\
\text { network) }\end{array}$ & $\begin{array}{l}\text { - Institutional } \\
\text { infrastructure } \\
\text { - Resolution (e.g., } \\
\text { living wills) } \\
\text { - Varying } \\
\text { information, } \\
\text { disclosure }\end{array}$ \\
\hline
\end{tabular}

\begin{tabular}{l}
\hline${ }^{a}$ Source: Claessens et al. (2013), Claessens (2014) \\
${ }^{a}$ Note: The table is not based only on a Basel III proposals (a global macroprudential framework), but contains the known tools used before the financial crisis of
\end{tabular} 2008 and the possible ones.

Table 1: Macroprudential toolkit 


\subsubsection{Basel III: New International Regulatory Framework for Banks}

The post-crisis paradigm of macroprudential policy in terms of Basel III regulatory accord aims to design and implement a policy that will prevent cross-market or cross-institution knockon effects that can enhance problems. Secondly, it aims to reduce the probability of financial system experiencing such knock-on effects. Hence, effective macroprudential policy could contain risks ex-ante and help build buffers as cushion to absorb shocks ex-post.

In terms of the global macroprudential regulation framework embodied in the Basel III regulatory accord (BIS 2010), macroprudential tools can be categorized into three broad classes: (i) capital-based tools (capital surcharges, sectoral capital requirements, countercyclical capital buffers and dynamic provisions, leverage ratios) ${ }^{4}$; (ii) liquidity-based tools (e.g.,liquidity coverage and net stable funding ratios ); and (iii) asset-based tools (e.g., limits on loan-to-value (LTV) and loan-to-income (LTI) ratios). ${ }^{5}$ The three classes of prudential instruments aim to increase the resilience to different types of financial shocks, although in different ways. In particular, the first group aims to improve the solvency of banks, the second one to resist during temporary liquidity shortages, and the last targets increasing the quality of the asset side of a banks' balance sheet.

Capital based tools. From the beginning of 2010, when the urgency of a new and strengthened regulatory framework for financial institutions became clear, the Basel Committee started to create a framework to increase the resilience of the banking sector. The Basel Committee reforms increase both the quality and quantity of the regulatory capital. These reforms are reinforced by a leverage ratio that should act as a backstop to the risk-based capital requirement. The leverage ratio aims to constrain excess leverage in the financial system and provide an extra layer of protection against measurement error and model risk. Moreover, the Basel Committee is introducing a series of instruments into the global capital framework to curb systemic risks arising from procyclical nature and the overconnectedness of financial institutions.

Basel III introduced a countercyclical capital buffer $(C C B)$ intending to reinforce financial institutions defences against the build-up of systemic vulnerabilities and to achieve the broader macroprudential goal of protecting the financial sector from periods of excess aggregate credit growth that have often been associated with the build-up of system-wide risk. The CCB introduces a time-varying buffer over and above the minimum bank "core capital requirement" stabilized by Basel Committee. ${ }^{6}$ The common approach to set capital requirements is through a static "floor" of a minimum capital requirement, which is well known to be procyclical (see Covas \& Fujita 2010, Andersen 2011, Repullo \& Suarez 2013, Behn et al. 2015). The countercyclical capital buffer is designed to tackle procyclicality in the financial system. It builds-up a capital buffer during periods of excessive credit growth. By increasing resilience during the expansion (upswing), the CCB supports the sustainable provision of credit to the economy in the contraction (downturn), and dampens the credit cycle during the upturn (see Figure 3).

The framework attributes the credit-to-GDP gap as a barometer to guide policymakers.

\footnotetext{
${ }^{4}$ Macroprudential leverage ratios differ from other instruments in the group by not being risk sensitive, instead being based on capital relative to total assets.

${ }^{5}$ For a transmission mechanism for each group of tools, see Committee on the Global Financial System (2012).

${ }^{6}$ In contrast to the minimum capital requirement of the pre-crisis Basel II framework (where total capital was subject to a limit of $8 \%$ of risk-weighted assets), Basel III is based on a higher quality capital component, meaning Core Tier 1 capital, and must be at least $4.5 \%$ of risk-weighted assets at all times.
} 


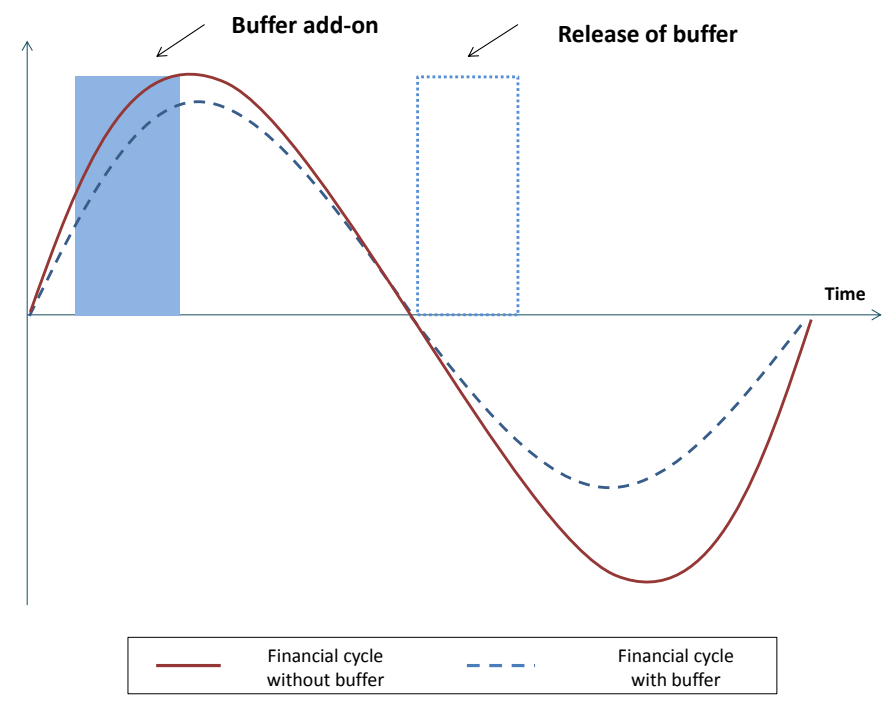

Figure 3: Buffer over the financial cycle

Early contributions to the debate on its efficiency as an early warning indicator of possible banking crises include studies by Borio \& Lowe $(2002,2004)$. Their findings were later confirmed for a large group of countries. ${ }^{7}$ Figure 3 helps assembling the analysis of when to "switch on" and/or increase the required buffer. The process of capital buffer creation follows three steps: (i) calculation of the aggregate private sector credit-to-GDP ratio; (ii) calculation of the creditto-GDP gap, defined as the difference between the credit-to-GDP ratio and its long-term trend; and (iii) transformation of the credit-to-GDP gap into the guide for buffer add-on. The size of the buffer add-on (in percent of risk-weighted assets) is zero when the credit-to-GDP gap $\left(G_{t}\right)$ is below a certain threshold $J .^{8}$ It then increases with $G_{t}$ until the buffer reaches its maximum level when the gap exceeds an upper threshold $H$. A Basel committee analysis found that an adjustment factor based on $J=2$ and $H=10$ provides a reasonable and robust specification, based on historical banking crises.

$$
C C B_{t}= \begin{cases}0, & \text { if } G_{t}<J \\ \frac{\left(G_{t}-J\right)}{(H-J)} * 0.025, & \text { if } J \leq G_{t} \leq H \\ 2.5, & \text { if } G_{t}>H .\end{cases}
$$

To be more clear, the guidance in Equation 1 suggests increasing the capital if the credit-to-GDP gap increases substantially above its trend value (e.g., up to $2.5 \%$ of risk-weighted assets if the credit-to-GDP gap rises above 10 percentage points).

Dynamic provisioning is a method that allows banks to build-up loan loss provisions during the expansion, and to withdraw such provisions during a contractionary phase of a cycle. There is no unique dynamic provisioning method. ${ }^{9}$ However, the fundamental principle is that provisions should be set on long-run estimates, based on through-the-cycle expected losses. This helps to

\footnotetext{
${ }^{7}$ See, for example, Drehmann \& Juselius (2014), Behn et al. (2013), and Borio \& Drehmann (2009).

${ }^{8}$ The buffer add-on under the Basel III global framework is realized on top of the core capital ratio of $4.5 \%$.

${ }^{9}$ For the different types of dynamic provisioning, including comparisons, see Mahapatra (2012), Wezel et al. (2012).
} 
break procyclicality and create countercyclical provision buffers. The general method of dynamic provisioning can be expressed as follows:

\section{Dynamic provisions $=$ Through-the-cycle loss ratio $*$ Flow of new loans - Flow of specific provisions}

As mentioned earlier, one of the underlying causes of the recent crisis was the build-up of excessive on- and off-balance sheet leverage in the financial system. Basel III regulatory accord will introduce a leverage ratio from 2018. The leverage ratio prevents excessive on- and offbalance sheet leverage by limiting banks' total assets to their equity. Because it is not based on risk-weighted assets (as in the case of the static capital requirement), it also provides a simple and transparent backstop to safeguard against model and measurement errors in the risk-based capital requirements.

$$
L R_{t}=\frac{\text { Tire } 1}{\text { TotalAssets }} \geq 3 \% .
$$

Capital surcharges for domestic and global systemically important financial institutions are imposed to contain systemic risks that originate from cross-exposures and interconnectedness in the financial system. The main goal is to limit the effect of contagion from the failure of this institutions, to discourage exposures to such institutions or to excessively large exposures within the financial system, more generally (See Arregui et al. 2013, Tabak et al. 2013, FSB 2014, Castro \& Ferrari 2014). An important advance is the determination of capital surcharges for global systemically important financial institutions (G-SIFIs) and domestic systemically important banks (D-SIBs) by the FSB and BIS, as an effort to achieve some degree of consistency of approach (BIS 2012, BCBS 2011b, FSB 2011b). ${ }^{10}$

The sectoral capital requirement applies a buffer of capital over and above microprudential floors on exposures to specific sectors or asset classes. In principle, a targeted increase in risk weights can be applied to any category of loans for which strong credit growth causes concern. This can include mortgage lending, unsecured consumer credit (or specific segments of such credit), and corporate lending (or specific corporate segments), such as lending for commercial property. An increase in risk weights is expected to increase loan interest rates for lending to the targeted sector, and can increase the resilience of lenders to a deterioration in credit quality.

Liquidity-based tools. The crisis has highlighted the systemic externalities associated with funding or market liquidity risk, and sparked a greater emphasis on liquidity tools that reduce vulnerabilities from a system-wide increase in wholesale, short-term funding (Bindseil \& Lamoot 2011, Hartlage 2012, Calomiris et al. 2014, Cooke et al. 2015). ${ }^{11}$ In contrast to the capital-based macroprudential instruments, at first, there was little consensus on appropriate liquidity-based instruments. Even before the financial crisis of 2008, microprudential liquidity regulations were still in the development stage. Thus, practical experience dealing with liquiditybased prudential tools with respect to capital-based instruments was rather limited. Even so, a range of liquidity-based macroprudential instruments have been suggested under the Basel III

\footnotetext{
${ }^{10}$ The additional capital surcharge on systemically important financial institutions is currently defined at a maximum of $3 \%$ and will be officially adopted from 2016 .

${ }^{11}$ Market liquidity is the ability to trade financial instruments at short notice with little impact on price. Instead, funding liquidity describes the ability to raise cash, either via the sale of an asset (balance sheet liquidity) or by borrowing. The two concepts of liquidity are closely interlinked.
} 
regulatory accord. Liquidity ratios, such as the liquidity coverage ratio (LCR) and net stable funding ratio (NSFR), are microprudential measures until their value is no longer attached to a variation in the macro environment. These tools guarantee the resilience of balance sheets of financial institutions to liquidity shocks, ensuring there is enough stock of highly liquid assets to cover unexpected outflows.

The LCR under the Basel III is based on standard liquidity "coverage" methodologies that were already adopted in internal management models by banks to assess exposure to stress events even before the financial crisis of 2008. The goal of the LCR is to promote the resilience of the liquidity risk under the unexpected short-term liquidity shortage scenario. The LCR aims to ensure that banking institutions have sufficient stock of unencumbered high-quality liquid assets (HQLA) that can be converted to cash at little or no loss of value in private markets. In this way, they can meet their liquidity needs in terms of net cash outflows (NCOF) for a 30-calendar day liquidity stress scenario (see Equation 3):

$$
L C R_{t}=\frac{H Q L A_{t}}{N C O F_{t}} \geq 100 \%
$$

where $H Q L A_{t}$ and $N C O F_{t}$ denote highly liquid assets and expected net cash outflows for a month-long liquidity stress scenario, respectively. ${ }^{12}$

The NSFR is defined as the ratio between the stock of available stable funding and the required stable funding, and should be not less than $100 \%$ on an on-going basis. "Available stable funding" refers to the share of capital and liabilities expected to be reliable over the time horizon considered by the NSFR (one year, according to the Basel III regulatory). The amount of described stable funding is a function of the liquidity characteristics and residual maturity of on-and off-balance sheet assets and exposures.

$$
N S F R_{t}=\frac{A A S F_{t}}{R A S F_{t}} \geq 100 \%
$$

where $A A S F_{t}$ and $R A S F_{t}$ denote the available amount of stable funding and the required amount of stable funding, respectively. ${ }^{13}$

Asset-based tools. Asset-based macroprudential instruments quantitatively limit credit by tightening borrowing constraints for targeted groups of borrowers. In practice, asset-based macroprudential instruments are often assigned to residential mortgages and other asset classes (e.g., commercial real estate, in India). Key examples of asset-side macroprudential instruments are limits on leverage activated on a specific group or on individual borrowers, such as LTV, LTI, or DTI (debt-to-income) caps. The release of LTVs, LTIs, and DTIs mainly influences the demand for credit (in the case of capital and liquidity requirements, the impact is on the supply of credit). The LTV ratio sets a cap on the size of a mortgage relative to the value of a property, thereby imposing a minimum down payment. The LTI and DTI caps impose constraints relative

\footnotetext{
${ }^{12}$ The "expected" net cash outflow refers to a special terminology of Basel III rule's definition. In practice, it does not refer to expectations in the classic meaning of the word. The "expectation of net cash outflow" refers to a computation of the possible cash outflows of bank balance sheet components, computed based on run-off rates of assets and liabilities.

${ }^{13}$ In line with the timeline documented in the 2010 publication of the international framework for liquidity risk measurement, standards, and monitoring, the NSFR will become a minimum standard by January 1, 2018 (see BCBS 2012, King 2013).
} 
to the income of borrowers. In this way, asset-based macroprudential instruments increase the resilience of the banking sector directly by dropping the probability of default (PD) and the loss-given-default (LGD) of loans.

\subsection{Macroprudential Policy: Relationship with Monetary Policy}

Before the financial turmoil of 2008, monetary policy was converging towards a single target, precisely inflation, and one tool, namely the short-term interest rate. During this period, financial stability was considered a distinct discipline from monetary stability. However, the post-crisis period made clear that price stability cannot be seen in isolation from financial stability, and that financial stability has a systemic dimension that cannot be ignored. Therefore, to guarantee macroeconomic stability, a macroeconomic policy has to adopt financial stability as an additional objective (Howitt 2011), together with macroprudential instruments that, constructed in a particular way, can target sources of financial imbalances.

As already mentioned, a key function of macroprudential policy is to moderate the procyclicality of the financial system by affecting the financial intermediation process. It operates on the leverage, assets, and liabilities of intermediaries. In this respect, macroprudential policy and monetary policy share some similarities. For instance, both policies affect the demand for credit by reallocating spending over time, by either postponing it (i.e., by inducing consumers and firms to borrow less) or bringing it forward (i.e., by inducing them to borrow more). Both policies affect the supply of credit by influencing the leverage decision and funding cost of the intermediary. ${ }^{14}$

However, there are two important differences between monetary and macroprudential policies. The first is that macroprudential policy is aimed at specific sectors or practices. In some respects, macroprudential policy harks back to the directed credit policies used by many advanced economies until the 1970s, although these were used to channel credit to favored sectors, as well as to constrain credit. The name is different, but the policies are similar. In many cases, it is "old wine in new bottles" (see Shin 2015). In contrast, monetary policy influences risk-taking more broadly, both within the domestic financial system and across borders, and is more difficult to circumvent. On the other hand, the broader impact of monetary policy cuts both ways, because domestic monetary policy is constrained by global conditions. This is the second difference between monetary policy and macroprudential policy.

It has long been recognized that monetary policy affects financial instability (Goodhart et al. 1988, Bradford \& Bagehot 1874). The literature has identified a number of channels through which monetary policy influences financial stability and macroprudential policy:

1. The borrower balance sheet or default channel: changes in the monetary policy affect the borrowing constraints and the probability of default. While monetary easing relaxes collateral constraints, stronger borrowing constraints can negatively affect the quality of borrowers, resulting in higher default rates (see the following seminal empirical papers Asea \& Blomberg (1998), Sengupta (2010), Altunbas et al. (2014), Jiménez et al. (2014) and Allen \& Gale (2000) and Goodhart et al. (2009) for theoretical support).

\footnotetext{
${ }^{14}$ For a comparison of the effects of monetary and macroprudential policies on financial market counterparties, see Figure 4.
} 

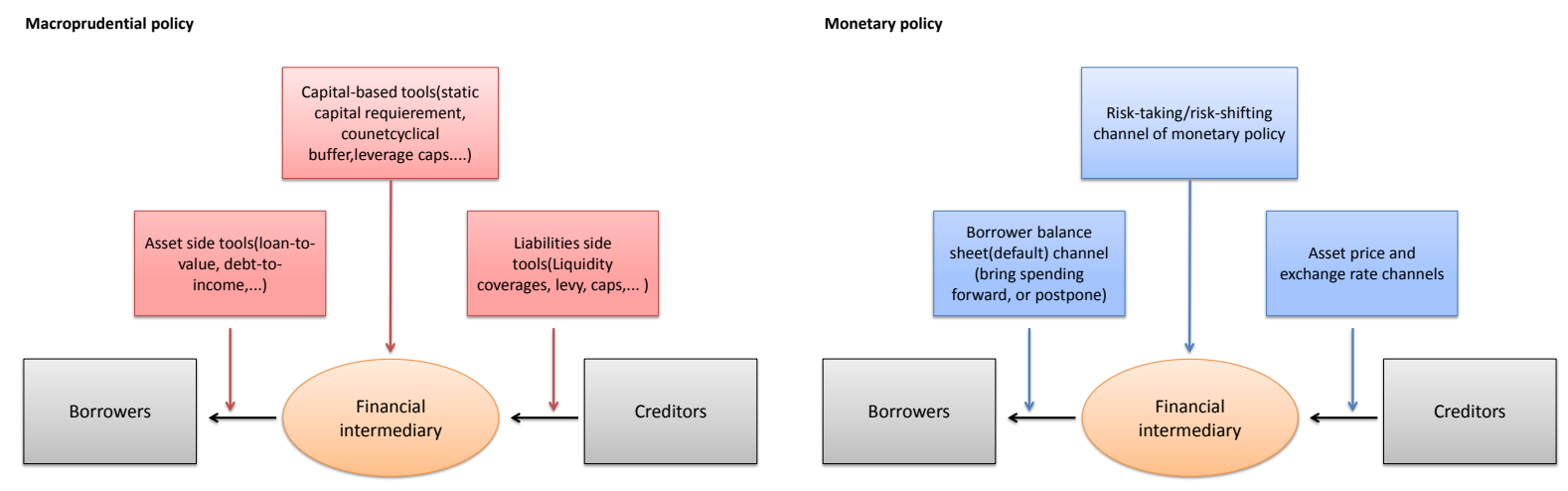

Figure 4: Impact of macroprudential and monetary policies on financial intermediation: a comparison

2. The risk-taking channel: an accommodative monetary policy can affect the risk-taking behavior of financial institutions (empirical evidence in Ioannidou et al. 2009, Nier \& Merrouche 2010, Borio \& Zhu 2012, Adrian \& Liang 2014, Jiménez et al. 2014). The monetary policy risk-taking channel describes how monetary policy measures, especially a change in the policy rate or the interest rate path, can alter the perception of risk or risk tolerance. For instance, low interest rates can create a stimulus to expand balance sheets, reduce screening efforts (Borio \& Zhu 2012), and, consequently, seek more risk associated with higher returns (Challe et al. 2013).

3. The risk-shifting channel: increases in policy rates can reduce intermediation margins and lead lenders to seek more risk (see more in Bhattacharya 1982, Gan 2004, Landier et al. 2011). This channel can be more pronounced during pre-crisis expansion, when intermediary leverage is high. More generally, a flattening of the yield curve associated with increases in policy rates can lead banks to seek risk in order to maintain profits.

4. The asset-price channel: by influencing aggregate financial prices, monetary policy can exacerbate negative externalities. Low interest rates can bring increases in asset prices, which can produce further increases in leverage (Benanke \& Gertler 1989, Kiyotaki \& Moore 1997, Bernanke et al. 1999, Del Negro \& Otrok 2007, Fatás et al. 2009, Altunbas et al. 2012). Conversely, a tightening of the monetary stance can cause collateral constraints to bind and fire sales to follow (Shin 2005). In open economies, interest rate hikes can attract capital flows, lead to excessive borrowing in foreign currency, and lay a foundation for exchange rate externalities (Hahm et al. 2012, Bruno \& Shin 2015).

5. The exchange rate channel: in an open economy, monetary policy can affect the exchange rate and capital flows. In bank-based systems, capital flows can, in turn, drive credit growth/contraction and, owing to the presence of exchange rate externalities, contribute to excessive increases/decreases in leverage. This poses a well-known dilemma, where raising domestic interest rates may induce excessive capital inflows and credit growth. Given the low policy rates in advanced economies, a number of emerging economies (e.g., Brazil, 
Peru, and Turkey) have been struggling with these problems (Jónsson 2009, Merrouche \& Nier 2010, Hahm et al. 2012).

At the same time, macroprudential measures can contain adverse effects for monetary policy, in that reducing policy dilemma, by creating additional room to maneuver for monetary policy and influencing its transmission mechanism. For example, limits on DTI ratios can weaken the impact on defaults from a tightening of monetary policy (Igan \& Kang 2011). LTV ratios can dampen asset price booms when accommodative monetary policy drives up asset prices (IMF 2011). Changes in LTV or DTI ratios can also change the supply of lending and, consequently, affect consumption decisions. Capital requirements and leverage ratios can help hold back increases in bank leverage in response to low policy rates and reduce risk-taking incentives (Farhi \& Tirole 2012). Moreover, by changing credit conditions, macroprudential policies could also influence the relevant real interest rate, indirectly modifying the monetary policy stance, even in the absence of any direct policy rate changes. Furthermore, macroprudential policies can affect output and inflation, because they directly affect credit flows. For instance, countercyclical capital buffers, apart from increasing the resilience of the banking system, can promote the proper transmission of monetary policy. This reduces the need for monetary authorities to compensate for the effects of tighter credit conditions on output, because the countercyclical buffers can help sustain the provision and serve as a cushion during the contractionary phase. In contrast, a lack of sufficient buffers may cause an erosion of capital, pushing the banks towards a cut in the credit supply. This can happen even when policy rates are lowered substantially. Today, macroprudential instruments are becoming an active part of post-crisis "new normal" macro policy. Thus, an intensive accumulation and an analysis of previous and current practical experience in the effectiveness of macroprudential instruments, and their interaction with monetary policy instruments, are needed.

The above-mentioned examples reflect the possible tensions in the simultaneous implementation of monetary and macroprudential policies. Macroprudential and monetary polices have substantially different sets of tools, as well as different goals. Although their intermediate targets and instruments differ, both policies have overlapping transmission mechanisms, because their field of influence passes through the financial system (see Figure 5). In other words, one shapes the playing field of the other. The effects of one policy need to be considered in the conception and implementation of the other. Thus, the two need to be coordinated, which is not easy, considering that financial and business cycles could be de-synchronized. At the same time, recalling the Tinbergen's principle (Tinbergen 1952), different policy goals call for different toolkits.

Theoretically, three different perspectives on the interaction between monetary policy and macroprudential policy are possible: (i) an idealized perspective, which holds that monetary policy should focus on price stability, and macroprudential policy should focus on financial stability and use its own toolkit to achieve that goal (two separate institutions, two goals, no overlapping interests); (ii) an extended perspective, in which financial stability is interpreted as an intermediate objective to the ultimate objective of sustainable price stability (two separate institutions, two goals, monetary policy considers financial instability signals, while making a monetary policy); and (iii) an integrated perspective, in which monetary policy adopts financial 


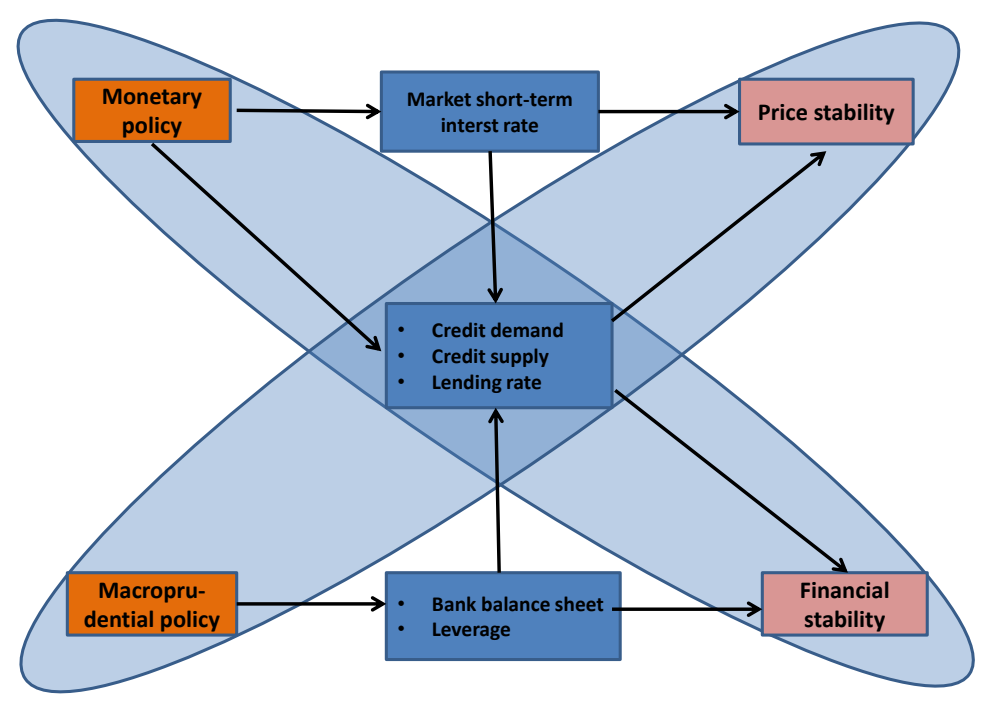

Figure 5: Monetary and macroprudential policy interactions

stability as a second objective. The idealized perspective is founded on the assumption that macroprudential policy is capable of reducing the key problems in its area, precisely and effectively. According to this perspective, the risk-taking channel of monetary policy is viewed as insignificant. IMF (2013) finds that the idealized perspective is an ideal scenario that would never practically materialize in the real world. The extended perspective represents a modification for the conduct of monetary policy: it should not focus, as before, exclusively on achieving a short-run inflation target, but must systemically incorporate the financial cycle into its decisions in order to safeguard price stability in the long run as well. Unlike the idealized perspective, the extended perspective assumes that it is impossible to eliminate an excessively pronounced financial cycle and, thus, risks to financial stability with these tools alone. In terms of monetary policy, financial stability is interpreted as an intermediate objective to the ultimate objective of sustainable price stability and, therefore, requires an extended policy horizon. The integrated perspective considers the separation of monetary policy and macroprudential policy to be inappropriate. Therefore, monetary policy encompass financial stability as a narrow objective as well. Strictly speaking, the integrated view advocates using both macroprudential and monetary policy instruments (standard and non-standard) in order to ensure financial stability, and, at the same time, price stability.

Over the past five years, many countries have accepted the importance of a strong governance framework for implementing macroprudential policy. I examine the emerging macroprudential governance models and their characteristics in EU member states and in OECD countries (see Table 2). From Table 2, two obvious models appear: (i) macroprudential policy is assigned either to a board, commissioned by different authorities, or (ii) to the central bank. Although having a central bank at the head of macroprudential policy governance has advantages, especially in terms of accountability and expertise, there may be good reasons for creating a macroprudential board. Typically, financial stability is affected by different policy fields, and identifying systemic 


\begin{tabular}{ll}
\hline \hline Macroprudential authority & Country \\
\hline \hline Central Bank & BE, CA, CY, CZ, EE, GR, HU, JP, IE, KR, LT, NZ, PT, SK, SZ \\
Supervisor & AU, FI, IL, SE \\
Government & NO \\
Board & AT, BG, CL, DE, DK, ES, FR, HR, IS, IT, LU, MX, NL, PL, RO, \\
& SI, TR, UK, US \\
\hline Central Bank & Board chaired by \\
Supervisor & CL, DK, ES, HR, IS, IT, NL, PL, RO, SI, TR, UK \\
Government & AT, BU, DE, FR, LU, US \\
\hline \hline Desighned authority & \\
\hline Central Bank & BE, BG, CA, CY, CZ, EE, GR, HR, HU, IE, JP, KR, LT, MX, \\
Supervisor & NL, NZ, PT, SK, SZ, UK, US \\
Government & AT, AU, DE, FI, FR, IL, SE \\
Board & DK, NO \\
\hline \hline
\end{tabular}

Source: EU and OECD Member States.

Note(a): AT-Austria; AU-Australia; BE-Belgium; BG-Bulgaria; CA-Canada; CL-Chile; CY-Cyprus; CZCzech Republic; DE- Germany; DK-Denmark; EE-Estonia; ES-Spain; FI- Finland; FR-France; JP-Japan; KR. Korea; UK- United Kingdom; GR-Greece; HU-Hungary; HR-Croatia; IE-Ireland; IL-Israel; IT-Italy; IS-Iceland LT-Lithuania; LU-Luxembourg; NO-Norway; NL-Netherlands; NZ-New Zealand; PL-Poland; PTPortugal; RO-Romania; SE-Sweden; SI-Slovenia; SK-Slovakia; SZ-Switzerland; TR- Turkey; US-United States of America.

Note(b): In case of France (FR) designated authority differs for different instruments. For a number of countries the designated authority is not known yet.

Table 2: Macroprudential authorities in EU and OECD countries

risks may benefit from combining different fields of expertise, as long as the committee has a clear macroprudential focus. Nevertheless, the involvement of several authorities may complicate decision-making and weaken accountability, increasing the risk of an inaction bias. For a board to be effective, its responsibilities and that of the participating authorities should be clear. This will most likely be the case if the central bank chairs the board (i.e., Denmark, Italy, Netherlands, Spain, etc.), although this is neither a sufficient nor a necessary condition. For a majority of countries, it is the central bank that decides on the use of the macroprudential tools aimed at banks. ${ }^{15}$ In a number of cases, these tools are assigned to the supervisor or the government (i.e., Finland, Sweden, Norway). Boards have only limited powers. Typically, they can issue non-binding recommendations to the respective authorities, but cannot decide on the use of macroprudential tools. Because countries have different legal and supervisory frameworks, it is no surprise that they have created different regulatory approaches. It remains to be seen which of these frameworks will create the institutional incentives and mechanisms to ensure that the authorities implement macroprudential tools in a timely and sufficient manner.

In the theoretical literature, the interaction mechanisms between the monetary and macroprudential policies are hotly debated. The main question that emerges is as follows. Are monetary policy and macroprudential policy effective only when they tighten at the same time, or it is possible to tighten one but loosen the other? In other words, must the two policies pull in the same direction (be used as complements), or can they pull in opposite directions (be used as substitutes)?

The majority of theoretical literature suggests that monetary and macroprudential policies

\footnotetext{
${ }^{15}$ That is, central banks are the designated authority in terms of the CRR/Capital Requirements Directive.
} 
have same effect in constraining credit growth, and that the two tend to be complements, not substitutes, although results vary by the type of financial shock (see in particular Ozkan \& Unsal 2014, Quint \& Rabanal 2014). The complementarity theory finds support in the so-called Tinbergen's principle, which claims that to achieve a certain number of independent policy objectives, there must be at least an equal number of tools (see Tinbergen 1952). ${ }^{16}$ For the issue at hand, considering macroeconomic stability and financial stability as the two policy objectives to be achieved, and following Tinbergen's principle, two separate tools are needed: the policy interest rate and a macroprudential instrument. At the same time, in view of the high degree of interconnectedness between the monetary and macroprudential policies, it is fundamental that macroprudential policies be assigned clear targets and given adequate instruments to implement them. Thus, a straightforward application of Tinbergen's principle stipulates that the objective of financial stability has to be paired with the necessary toolkit.

Models by Agénor et al. (2013) and Unsal (2011) document that when negative financial shocks lead to distortions in financial stability, macroprudential policies are optimal, because these tools are more targeted at the specific financial sector distortion, whereas monetary policy has a "short hand". Their results are also robust in open economy cases. In open economies, financial shocks can originate abroad, leading to an appreciation of the domestic currency. While this limits inflation, when banks have foreign liabilities, it leads to financial amplification by strengthening banks' balance sheets, causing credit to expand. As a result, macroprudential policy needs to react more and monetary policy needs to react less, but the interplay between the two does not change markedly.

In the case of the DSGE models with a productivity shock, the results greatly depend on the characteristics of the financial distortions. According to the DSGE models, where only borrower collateral constraints are present (such as Unsal 2011, Bailliu et al. 2012, Beau et al. 2012, Kannan et al. 2012, Cecchetti \& Kohler 2012), the results show that only monetary policy should be used. Limiting credit is misguided, and runs counter to the stimulus provided by monetary policy. DSGE models with endogenous financial distortions (such as Brunnermeier \& Sannikov 2014a, Lambertini et al. 2013, Christensen et al. 2011) find opposite conclusions. Because lending by individual banks affects overall riskiness, it is optimal to tighten macroprudential policy to restrain the credit growth. However, the monetary policy response to inflation remains unchanged from what is traditionally found. Practically, the appropriate policy mix will vary, depending on the strength and expected persistence of the productivity shock, as well as the riskiness of balance sheets, including capital buffers and leverage. A similar discussion applies to an aggregate demand shock. A monetary policy response alone is optimal if it durably stabilizes both inflation and output. When stabilizing inflation comes at the cost of lost output, and when lending imposes a systemic risk externality, there is some scope for using macroprudential policy alongside monetary policy in order to limit the systemic risk stemming from the expansion in leverage.

Another modeling framework, agent-based models, assign more than one objective to the

\footnotetext{
${ }^{16}$ Tinbergen (1952) showed that a policy can only attain a specified number of targets with precision if it is endowed with the same or greater number of instruments. This does not necessarily mean that each instrument needs be targeted at one and only one objective-only that an adequate number of instruments must be available in order to achieve all the policy objectives.
} 
monetary policy instrument in order to achieve price, output, and financial stability simultaneously. This framework confirms the expected proposition of Tinbergen's principle (Tinbergen 1952) in that it is not possible to improve the financial stability and the traditional monetary policy goals. Hence, while adopting the "leaning-against-the-wind" policy, the central authorities (also targeting financial stability) need to adopt macroprudential tools (see Krug 2015, Capter 3 of the thesis).

\section{A Literature Review of Macroprudential Policy}

A consensus on the contours of a new macroprudential policy framework has not yet been reached. The literature providing an impact/effectiveness analysis of macroprudential policy tools and the ways that monetary and macroprudential policies interact is still in its infancy, and provides limited policy advice. Ultimately, the number of policy speeches, research contributions, and conferences that debate the macro perspective of financial regulation, and the efficiency of the latter, has grown considerably (the notable contributions are Vandenbussche et al. 2015, Brzoza-Brzezina et al. 2015, Freixas et al. 2015, Angelini et al. 2014, Geanakoplos 2014, Leeper \& Nason 2014, Zhang \& Zoli 2016, Claessens et al. 2013, Benigno et al. 2013). In addition, progress at the empirical and theoretical levels offers new perspectives and ways to reshape older ideas to meet new challenges. ${ }^{17}$ Table 3 provides a summary of recent studies on the effects of various macroprudential regulation tools, as well as their interactions with monetary policy. In particular, the next two sections (3.1-3.2) analyse theoretical and empirical contributions focusing on efficiency of macroprudential instruments and coordination issues of monetary and macroprudential policies.

\subsection{Empirical Studies on Macroprudential Policy}

Empirical findings on macroprudential instruments and on their effectiveness are few because of the scarcity of established models on the interaction between the financial system and the macroeconomy, and the scarcity of data needed to conduct empirical analyses. ${ }^{18}$ This is also partially driven by the differences in sample coverage and underlying policy studies (see more in Cerutti et al. 2015). The main source of existing empirical analyses is data on asset-based instruments aiming at borrowers, such as caps on LTV and DTI ratios (see McDonald 2015, Cerutti et al. 2015, Zhang \& Zoli 2016, Claessens et al. 2013), static capital requirements (see Vandenbussche et al. 2015, Duca \& Ling 2015, Aiyar et al. 2014, among others), and institutionbased policies, such as dynamic provisioning as a prototype of a countercyclical capital buffer (see in Cussen et al. 2015, Aiyar et al. 2014, Lim et al. 2013, Maddaloni \& Peydro 2013, Miles et al. 2013, Shim et al. 2013), which was in use even before the financial crisis of $2008 .{ }^{19}$

The empirical literature on the use of macroprudential tools, as well as their effectiveness, can be divided into two groups. The first group includes cross-country panel studies that analyze the

\footnotetext{
${ }^{17}$ For detailed literature reviews see Galati \& Moessner (2014) and Claessens (2014).

${ }^{18}$ The main part of global macroprudential instruments are not applied in practice. For example, LCR will become a minimum requirement from January 1, 2019, and the leverage ratio will become a minimum requirement from January 1, 2018.

${ }^{19}$ For the possible and existing macroprudential instruments, see Table 1.
} 


\begin{tabular}{|c|c|c|c|c|}
\hline $\begin{array}{l}\text { Author(s) of } \\
\text { contribution }\end{array}$ & Framework & Tool analyzed & $\begin{array}{l}\text { Impact of } \\
\text { instrument }\end{array}$ & $\begin{array}{l}\text { Interaction } \\
\mathrm{MoP} / \mathrm{MaP}\end{array}$ \\
\hline \multicolumn{5}{|c|}{ Monetary/macroprudential policy interactions } \\
\hline Popoyan et al. (2015) & $\mathrm{ABM}$ & $\mathrm{CAR}+\mathrm{CCB} / \mathrm{LR} / \mathrm{LCR}$ & + & COMP \\
\hline Benes \& Kumhof (2015) & DSGE & CAR & + & COMP \\
\hline Brzoza-Brzezina et al. (2015) & DSGE & LTV & + & COMP \\
\hline Krug (2015) & $\mathrm{ABM}$ & $\mathrm{CAR}+\mathrm{CCB} / \mathrm{LR}$ & + & COMP \\
\hline Popoyan et al. (2015) & $\mathrm{AMB}$ & $\mathrm{CAR}+\mathrm{CCB}, \mathrm{LR}, \mathrm{LCR}$ & + & COMP \\
\hline Alpanda et al. (2014) & DSGE & $\mathrm{LTV} / \mathrm{CAR}$ & + & COMP \\
\hline Fisher (2014) & $\mathrm{CC}$ & $\mathrm{CAR} / \mathrm{LCR}$ & + & COMP \\
\hline Guzman \& Roldos (2014) & DSGE & $\mathrm{RR}$ & + & COMP \\
\hline Ozkan \& Unsal (2014) & DSGE & CAR & - & COMP \\
\hline Quint \& Rabanal (2014) & DSGE & CAR & $+/-$ & COMP \\
\hline Suh $(2014)$ & DSGE & CAR & - & COMP \\
\hline Zilberman \& Tayler (2014) & DSGE & $\mathrm{CAR}+\mathrm{CCB}$ & + & COMP \\
\hline Agénor et al. (2013) & DSGE & $\mathrm{CAR}+\mathrm{CCB}$ & + & COMP \\
\hline Angeloni \& Faia (2013) & DSGE & CAR & + & COMP \\
\hline Lambertini et al. (2013) & DSGE & LTV & + & COMP \\
\hline Smets (2013) & $\mathrm{CC}$ & $\mathrm{CAR}+\mathrm{CCB} / \mathrm{LR} / \mathrm{LCR}$ & + & COMP \\
\hline Kannan et al. (2012) & DSGE & LTV & + & COMP \\
\hline Suh $(2012)$ & DSGE & $\mathrm{CAR} / \mathrm{LTV}$ & - & COMP \\
\hline Angelini et al. (2011) & DSGE & $\mathrm{CAR}+\mathrm{CCB} / \mathrm{LTV}$ & + & COMP \\
\hline Christensen et al. (2011) & DSGE & LR & $+/-$ & COMP \\
\hline \multicolumn{5}{|c|}{ Impact of the prudential tools } \\
\hline Zhang \& Zoli (2016) & Empirical & LTV & + & \\
\hline Bruno et al. (2015) & Empirical & CAR & + & \\
\hline Cerutti et al. (2015) & Empirical & $\mathrm{LTV} / \mathrm{DTI} / \mathrm{LR} / \mathrm{DP}$ & + & \\
\hline Cussen et al. (2015) & Empircal & $\mathrm{LTV} / \mathrm{CAR}$ & + & \\
\hline McDonald (2015) & Empirical & LTV & + & \\
\hline Da Silva \& Lima (2015) & $\mathrm{ABM}$ & $\mathrm{CAR}+\mathrm{CCB}$ & + & \\
\hline van der Hoog (2015) & $\mathrm{ABM}$ & LR & + & \\
\hline Vandenbussche et al. (2015) & Empirical & $\mathrm{CAR} / \mathrm{MMP}$ & + & \\
\hline Aiyar et al. (2014) & Empircal & CAR & - & \\
\hline Brunnermeier \& Sannikov (2014a) & DSGE & $\mathrm{LR} / \mathrm{CAR}$ & - & \\
\hline He \& Krishnamurthy (2014) & DSGE & $\mathrm{LR} / \mathrm{CAR}$ & + & \\
\hline Krug et al. (2015) & $\mathrm{ABM}$ & $\mathrm{CAR}+\mathrm{CCB} / \mathrm{LCR} / \mathrm{LR}$ & + & \\
\hline Balasubramanyan \& VanHoose (2013) & $\mathrm{ST}$ & LCR & $+/-$ & \\
\hline Benigno et al. (2013) & DSGE & CAR & - & \\
\hline Bianchi \& Mendoza (2013) & DSGE & LR & - & \\
\hline Boissay et al. (2013) & DSGE & $\mathrm{LCR}$ & + & \\
\hline Claessens et al. (2013) & Empirical & LTV & + & \\
\hline Crowe et al. (2013) & Empirical & $\mathrm{LTV} / \mathrm{DTI}$ & + & \\
\hline Kuttner \& Shim (2013) & Empirical & $\mathrm{DTST} / \mathrm{LTV}$ & + & \\
\hline van den End \& Kruidhof (2013) & $\mathrm{ST}$ & LCR & - & \\
\hline Adrian \& Boyarchenko (2012) & DSGE & LR & + & \\
\hline Cincotti et al. (2012) & $\mathrm{ABM}$ & CCB & + & \\
\hline Dell'Ariccia et al. (2012) & Empirical & $\mathrm{LTV} / \mathrm{DTI}$ & + & \\
\hline Lim et al. (2011) & Empirical & LTV & + & \\
\hline van den End \& Tabbae (2012) & $\mathrm{ST}$ & LCR & + & \\
\hline Pariès et al. (2011) & DSGE & CAR & - & \\
\hline
\end{tabular}

Note: DSGE = Dynamic Stochastic General Equilibrium Model; CC = Constructive Criticism (studies do not provide an analysis within a traditional model framework. The component's impact is based on logical reasoning followed by a discussion of potential alternatives); $\mathrm{ABM}=$ Agent-based Model; $\mathrm{ST}=$ Stress-test models; COMP = in contribution monetary and macroprudential policies are compliments; CAR = Capital Adequacy Requirement; CCB-Countercyclical Capital Buffer; LCR = Liquidity Coverage Ratio; LTV-Loan-to-Value; LR-Leverage Ratio; RR-Reserve Requirement; MMR-Marginal reserve requirement; DTI $=$ Debt-to-income; DSTI $=$ Debt-service-to-income.

Table 3: Studies on the interaction of macroprudential/monetary policy and impact of macroprudential tools 
links between macroprudential policy tools and financial indicators (i.e., credit growth, leverage, house prices, capital inflows, etc.). Within this group, two distinct subgroups are emerging: (i) cross-country contributions, focusing on asset-based tools (i.e., LTV, DTI, etc.), and (ii) crosscountry studies focusing on capital-based tools. The second group leans on micro data evidence, covering either individual banks balance sheet items or household borrowings.

Empirical studies on asset-based tools are the most diffuse, due to data availability issues. One of the first cross-county panel studies focusing on asset-based macroprudential instruments was analysis by Lim et al. (2011). They analyze the links between macroprudential policy tools and developments in credit and leverage. They find evidence of macroprudential policy dampening procyclicality, mainly through credit-related measures (e.g., LTV, DTI caps). Similar results are obtained by Dell'Ariccia et al. (2012). They find that macroprudential instruments can reduce the incidence of general credit booms and decrease the probability that booms will have further catastrophic impacts. They also highlight that macroprudential policies can reduce the risk of a bust, while simultaneously reducing how the rest of the economy is affected by troubles in the financial system. Moreover, the empirical results document that LTV ratios can have a strong effect on house prices and aggregate demand (IMF 2013), which can justify a gradual approach to tightening these ratios (as in Canada and the Netherlands). Another study focusing on asset-based prudential instruments is that of Claessens et al. (2013), who provide bank-level evidence of balance sheet sensitivity in 48 countries for the period 2000-2010. They find that instruments aimed at borrowers - LTV and DTI caps, and limits on credit growth - effectively reduce a bank's leverage, assets, and non-core to core liabilities growth during the expansionary phase of an economy. Practically, LTV and DTI can reduce the feedback between credit and prices in an upswing, and improve resilience to shocks. This reduces the probability of default and boosts the recovery values when the housing market turns (see also Crowe et al. 2013). Cerutti et al. (2015) propose the most complex cross-country empirical analysis on asset-based prudential tools (119 countries over the period 2000-2013) and find that foreign exchange-related macroprudential policies are used more frequently in emerging economies, while borrower-based policies are used more in advanced countries. They show that using macroprudential policies can be associated with relatively greater cross-border borrowing, suggesting that countries face issues of avoidance. Cerutti et al. (2015) also find evidence of asymmetric impacts of macroprudential policies: some work better in a boom than in a bust phase of a financial cycle.

Some cross-country contributions on asset-based prudential tools focus on the real estate market and house price dynamics. Using data from 57 countries, and spanning more than three decades, Kuttner \& Shim (2013) examine the effectiveness of macroprudential measures in stabilizing house prices and housing credit. Applying panel regression methodologies, they show that housing credit growth is significantly affected by changes in the maximum debt-service-toincome (DSTI) ratio, the maximum LTV ratio, limits on exposure to the housing sector, and housing-related taxes. Among the above policies, a change in housing-related taxes is the only regulatory policy tool with a discernible impact on house price appreciation. Ahuja \& Nabar (2011), Crowe et al. (2013), and IMF (2011) find that LTV and DTI caps decelerate property price growth, slow property lending growth, contain feedback between credit and prices in an 
upswing, and improve the resilience to shocks. Thus, these caps reduce default rates and boost recovery values when the housing market turns.

Cross-country studies covering capital-based tools are less common because these tools are newly designed and not fully implemented. That is why these studies focus mainly on static capital requirements. One of the most recent studies, Zhang \& Zoli (2016), reviews macroprudential instruments and capital flow measures using a data sample of 13 Asian and 33 other economies, starting from 2000. They conduct their analysis based on constructed macroprudential policy indices and aggregated sub-indices on key instruments. Their analysis suggests that macroprudential policy and capital flow measures have helped restrain housing price growth, equity flows, credit growth, and bank leverage. The instruments that have been particularly effective in this regard include LTV caps, housing tax measures, and foreign currency-related measures. Carrying the same line of Zhang \& Zoli (2016) study, based on data of 12 AsiaPacific countries, Bruno et al. (2015) investigate the relationship between macroprudential and capital flow management tools. They find that banking sector and bond market capital flow management tools are effective in slowing down bank and bond inflows, respectively.

The second group of contributions were conducted using micro-level data, and are mostly analyses of one or a few macroprudential policies. Jiménez et al. (2012), using Spanish microdata, find that countercyclical dynamic provisioning in Spain smoothed the credit cycles and in bad times supported firms' financing and performance. However, the provisioning did not contribute sufficiently to stopping the credit boom in good times (see Saurina 2009). Using sectoral micro-data, Wong et al. (2011) and Igan \& Kang (2011) show that the LTV and DTI ratio caps effectively decreased the systemic risk caused by house price cycles in Hong Kong and Korea. Aiyar et al. (2014) examines micro evidence using a UK data set for the period 1998-2007. They found that there is a statistically significant response between the changes in banks capital requirement and credit supply (see also Kato et al. 2010, Lim et al. 2013).

\subsection{Theoretical Approaches in Macroprudential Policy}

As we can see from Table 3, the vast majority of theoretical literature examines the efficiency of macroprudential tools and the interaction between macroprudential and monetary policy in theoretical dynamic stochastic general equilibrium (DSGE) models, while other categories of models (i.e., agent-based simulated models and stress-testing model) are the obvious minority.

In DSGE theoretical frameworks, the macroprudential policy is addressed from two specific aspects: i) with borrower collateral constraints and a banking sector (see in particular BrzozaBrzezina et al. 2015, Agénor et al. 2013, Lambertini et al. 2013, Angelini et al. 2011), and ii) with a financial accelerator, as in Bernanke et al. (1999) (see more in Quint \& Rabanal 2014, Ozkan \& Unsal 2014, Suh 2014, Kannan et al. 2012, Suh 2012). In these models, monetary policy controls the risk-free interest rate, and macroprudential policy controls the risk premium, or the spread between lending rates and the risk-free rate. Two main questions are analyzed below, based on a theoretical DSGE model. Does macroprudential policy have a positive impact on welfare and macroeconomic outcomes? Should monetary policy respond to developments in the financial markets, despite the existence of macroprudential policy? 
While answering these questions, Brzoza-Brzezina et al. (2015) find in their DSGE model of the euro area ("core" and "periphery" countries) that appropriate adjustments in the LTV ratio can substantially lower the volatility of credit and output in the periphery. They also find that macroprudential policy is particularly efficient at trading off monetary policy shocks and shocks related to the housing market. Their welfare analysis also points in this direction. A similar conclusion was drawn by Lambertini et al. (2013), who consider a model of the housing market and study the potential gains of monetary and macroprudential (in terms of countercyclical LTV ratio) policies that lean against house-price and credit cycles. They find that the policy that responds to changes in financial variables is socially optimal. The optimal policy for borrowers is characterized by an LTV ratio that responds countercyclically to credit growth, which most effectively stabilizes credit relative to GDP (see also Alpanda et al. 2014). Lambertini et al. (2013) also find that a countercyclical LTV rule, responding to credit growth, can stabilize the economy better than the interest rate can. Another study focusing on the housing market is that of Kannan et al. (2012), who show that strong monetary reactions to accelerator mechanisms, which push up credit growth and house prices, can help macroeconomic stability. In addition, using a macroprudential instrument such as the LTV ratio, specifically designed to dampen credit market cycles, would provide stabilization benefits when an economy faces financial sector or housing demand shocks. However, the optimal macroprudential rule under productivity shocks is to not intervene.

Under the theoretical DSGE models, capital requirements receive most of the attention in terms of an efficiency tool. Angelini et al. (2011) and Christensen et al. (2011) develop DSGE models for the banking sector, reporting stabilization effects from a countercyclical capital requirement introduced by the new Basel III regulatory framework. Christensen et al. (2011) also find stabilizing gains from countercyclical bank leverage regulation, as an optimal response to financial shocks, and lower efficiency of the same rule in the case of technological shocks. Alpanda et al. (2014), studying the effectiveness of different macroprudential policy tools, show that, in terms of reducing household debt, sector-targeted instruments such as capital regulations are the most efficient and least costly for reaching both macroeconomic and financial stability. Suh $(2014,2012)$ examine the different effects of capital requirements on credit and inflation in a simple New Keynesian model framework. In both models, macroprudential policy stabilizes credit growth, but has a neutral effect on inflation. Instead, monetary policy with an interest rate rule stabilizes inflation, but is "too blunt" an instrument to stabilize credit.

DSGE studies that look for combinations of macroprudential and monetary policies mainly follow on the credit-augmented Taylor rules, and "leaning-against-the-wind" monetary policy. One of the fist studies to examine a macroprudential-monetary policy combination was the model proposed by Angeloni \& Faia (2013). They find that the best combination of monetary and macroprudential policies includes mildly anticyclical capital ratios and the response of monetary policy to asset prices or bank leverage. Following this stream of literature, Ozkan \& Unsal (2014) analyze optimal monetary and macroprudential policy rules for a small, open economy. The study points out that, following a financial shock, "leaning-against-the-wind" helps achieving macroeconomic and financial stability. Under a productivity shock, it is more costly, from a welfare point of view, to respond to financial market developments using mone- 
tary policy than using a macroprudential policy. Instead, Guzman \& Roldos (2014) found slight differences from the study of Ozkan \& Unsal (2014). Despite showing that the countercyclical reserve requirement delivers clear welfare gains, they show that the credit-augmented Taylor rule delivers a substantial improvement to the classic Taylor rule. Quint \& Rabanal (2014) study the impact of jointly optimal monetary and macroprudential policies on the macro performance of an economy. They find that the introduction of a macroprudential policy helps reduce macroeconomic volatility, provides more welfare gains, and partly substitutes for the lack of national monetary policies. Moreover, they showed that macroprudential policies may reduce accelerator effects. According to Quint \& Rabanal (2014), macroprudential policy in the majority of cases increases the welfare of savers, but the effect on borrowers depends on the nature of the shock that hits the economy. A similar conclusion came from Agénor et al. (2013) while examining the policy mix of banks capital regulations and monetary policy in reducing procyclicality, ensuring macroeconomic and financial stability in a closed economy DSGE model. Exercises of housing demand shocks show that a policy combination of a credit-augmented interest rate rule and a countercyclical capital requirement, akin to the Basel III regulatory framework, may be optimal to guarantee both monetary and financial stability.

Another generation of models that discuss the effects of macroprudential policy and the interaction between that and monetary policy use simulation techniques. Within this class of models two approaches are emerging: agent-based models (Tesfatsion \& Judd 2006, LeBaron \& Tesfatsion 2008) and stress-testing models (Alexander \& Sheedy 2008, Borio et al. 2014).

AMBs are successfully being used to model interacting schemes between monetary and macroprudential policies. Krug (2015) contributes to the field of macroprudential regulatory impact assessment by addressing the question of whether central banks should "lean-againstthe-wind". He shows that "leaning-against-the-wind" should only serve as a first line of defense in the absence of a prudential regulatory regime and, in this context, price stability does not necessarily mean financial stability. Moreover, he shows that macroprudential regulation is able to dampen the build-up of financial imbalances by restricting credit to the unsustainable highleverage part of the real economy. Another study using an ABM as a modeling framework for policy assessment is the contribution by Da Silva \& Lima (2015). They study different combinations of interest rate and capital requirements in terms of macroeconomic and financial stability (see also Dosi et al. 2013, 2015). They find that the adoption of a countercyclical capital rule under Basel III regulatory framework is efficient in achieving financial stability when used on its own, but performs worse when it is combined with some interest rate rules. Contributing to the debate of monetary and macroprudential policy combination schemes, Popoyan et al. (2015) show that a credit-augmented Taylor rule, focused on the output gap, inflation, and credit growth, and using a Basel III prudential regulation is the best policy mix to improve the stability of the banking sector and to smooth output fluctuations. Moreover, they find that the minimum capital requirements and countercyclical capital buffers allow results close to the Basel III first-best, but with a far simpler regulatory framework (Haldane \& Madouros 2012, Aikman et al. 2014).

Another stream of literature is assessing the macroprudential policy with stress-test models. ${ }^{20}$

\footnotetext{
${ }^{20}$ Stress-testing models are simulated models that test the stability of an entity or system under adverse conditions and shocks. In comparison to ABMs those models consider a single part of overall system and the
} 
van den End \& Tabbae (2012) present a macro stress-testing model assessing banks' liquidity risks when Basel III liquidity regulations (LCR and NSFR) are in action and unconventional monetary policy and credit supply effects are present. The results show that liquidity rules under the Basel III regulatory accord limit liquidity risk and promote higher quality liquid asset holdings. In another contribution, van den End \& Kruidhof (2013) simulate the systemic implications of the LCR using a liquidity stress-testing model, and find that if in extreme scenarios, the LCR becomes a binding constraint, the interaction of bank behavior with the regulatory rule can have negative externalities. They show too that a flexible LCR approach, particularly one that recognizes less liquid assets in the buffer, is a useful macroprudential instrument to mitigate the adverse side effects during times of stress. At extreme stress levels, the instrument becomes ineffective and the lender of last resort has to underpin the stability of the system. ${ }^{21}$

\subsection{Generalized Picture of Literature on Macroprudential Policy}

A closer examination of the literature on macroprudential policy shows four particularly interesting facts. First, the majority of contributions focus on an analysis and impact of static prudential tools and, as a consequence, the new countercyclical macroprudential regulation tools, which are a milestone of the new Basel III accord, are not considered (Brzoza-Brzezina et al. 2015, Alpanda et al. 2014, Ozkan \& Unsal 2014).

Second, few studies analyze the impact and the interaction mechanism of more than one component of the post-crisis macroprudential regulation (Popoyan et al. 2015, Krug et al. 2015, Angelini et al. 2011). The majority of studies consider the standalone impact of prudential tools.

Third, there are few empirical analyses of macroprudential tools because of the scarcity of established models showing the interaction between the financial system and the macroeconomy, and the scarcity of data needed to conduct empirical tests. One of the reasons is that the main part of global macroprudential instruments are not applied in practice. ${ }^{22}$ Notwithstanding a scarcity of data, existing empirical studies manage to shed light on the efficiency of some assets and capital-based tools. In particular, borrower-based instruments (such as LTV and DTI caps) appear to be able to dampen the procyclicality, reduce the incidence of general credit booms and the feedback between credit and prices in upswings. In addition, they improve the resilience to shocks and decrease the probability that booms will end badly (see, in particular DellAriccia et al. 2012, IMF 2013, Claessens et al. 2013, Cerutti et al. 2015). With regard to capitalbased tools, empirical evidence focuses more on static capital requirements and on capital flow management tools. Specifically, the analysis suggests that macroprudential policy and capital flow measures have helped curb housing price growth, equity flows, credit growth, and bank leverage (Zhang \& Zoli 2016, Bruno et al. 2015). In addition, there is a statistically significant relationship between the variations in a static capital adequacy rule and the banks' credit supply (Aiyar et al. 2014).

\footnotetext{
shock are mainly exogenous.

${ }^{21}$ See more on the negative effect of LCR in Schmitz (2013), van den End \& Tabbae (2012).

${ }^{22}$ The NSFR will become a minimum standard by January 1, 2018 (see BCBS 2012), 100\% of the LCR will become a minimum standard from January 1, 2019 (see BCBS 2013). The leverage ratio will become a minimum requirement from January 1, 2018.
} 
Fourth, the few studies that, at least partially, analyze the impact of Basel III's macroprudential instruments and the interaction of the latter with monetary policy, use dynamic stochastic general equilibrium (DSGE) framework (Brunnermeier \& Sannikov 2014a, He \& Krishnamurthy 2014, Angelini et al. 2011). These models, even when incorporating financial frictions, describe financial crises as huge negative shocks and cannot capture the fact that crises are rare events resulting from "credit booms gone wrong", followed by deep and long recessions (for more see Dosi et al. 2015, Boissay et al. 2013, Dosi 2012, Fagiolo \& Roventini 2012, Stiglitz 2011, Colander 2010). Although it is crucial, especially for an efficient analysis of macroprudential tools, the interaction and coordination between economic agents and, hence, between the real and financial sectors, and between financial sector elements is completely neglected. Hence, the suitability of these models to analyzing crises, namely situations where an economy is out of equilibrium, using an equilibrium approach can be questioned. Furthermore, under the framework of the DSGE model, analyses using the same tool give controversial results in different models. These conflicts depend on the nature of the shocks impacting the economy (for more details see IMF 2013). With all the limitations of DSGE models, it is important to remember the scarce ability of DSGE models to analyse the issues of macroprudential and monetary policy interactions. The aim of macroprudential policy is to identify systemic risks at an early stage and, ideally, to avert them. DSGE models typically cannot capture systemic risk; and the newly developed DSGE models that include systemic risks are still too abstract to be able to capture the interaction between monetary and macroprudential policies (e.g., Brunnermeier \& Sannikov 2014b, Bianchi 2014). The DSGE models surveyed were developed to represent relatively small fluctuations in the model variables around a stable long-term equilibrium ("steady state"). Thus, important features of financial crises - such as an abrupt drop in asset prices, fire sales of securities, or runs on financial market institutions-can only be described to a limited extent.

Bearing this caveat in mind, another class of modeling approach, namely agent-based models $(\mathrm{ABM})$, propose using a more adopted methodology to assess policy interaction schemes. ${ }^{23}$ Those models are able to explain an economic cycle based on the complex functioning of an economy, without any exogenous shocks (Ashraf et al. 2011, Dosi et al. 2013, 2015). Consequently, there is a cascade of bankruptcies arising from the complex nature of agent interactions. ABMs focusing on efficiency of macroprudential policy and its interaction with monetary policy have demonstrated already very complex and converging results. In particular, Krug (2015), Krug et al. (2015) and Popoyan et al. (2015) found that it is beneficial for an economy if the combination of macroprudential and monetary policies follow the Tinbergen's principle. Moreover, together with Krug (2015), Krug et al. (2015), Popoyan et al. (2015) document a stabilizing effect of countercyclical capital requirement and marginal role of liquidity and leverage requirements.

Notwithstanding a scarcity of data, existing empirical studies manage to shed light on the efficiency of some assets and capital-based tools. In particular, borrower-based instruments (such

\footnotetext{
${ }^{23}$ For relevant macroeconomic agent-based models with credit and financial markets, see Delli Gatti et al. (2005, 2010), Ashraf et al. (2011), Gai et al. (2011), Battiston et al. (2012b), Cincotti et al. (2012), Geanakoplos et al. (2012), Raberto et al. (2012), Teglio et al. (2012), Dosi et al. (2010, 2013, 2015), Lengnick et al. (2013), Riccetti et al. (2013), Dawid et al. (2014), Krug et al. (2015), Krug (2015), Napoletano et al. (2015), Seppecher \& Salle (2015), Da Silva \& Lima (2015), van der Hoog \& Dawid (2015), van der Hoog (2015), and the papers in Gaffard \& Napoletano (2012). See Fagiolo \& Roventini (2012) and Fagiolo \& Roventini (2016) for a critical comparison of macroeconomic and financial policies in standard DSGE and agent-based models, and Guerini et al. (2016) for an ABM comparable to a plain-vanilla New Keynesian DSGE model.
} 
as LTV and DTI caps) appear to be able to dampen the procyclicality, reduce the incidence of general credit booms and the feedback between credit and prices in upswings. In addition, they improve the resilience to shocks and decrease the probability that booms will end badly (see, in particular DellAriccia et al. 2012, IMF 2013, Claessens et al. 2013, Cerutti et al. 2015). With regard to capital-based tools, empirical evidence focuses more on static capital requirements and on capital flow management tools. Specifically, the analysis suggests that macroprudential policy and capital flow measures have helped curb housing price growth, equity flows, credit growth, and bank leverage (Zhang \& Zoli 2016, Bruno et al. 2015). In addition, there is a statistically significant relationship between the variations in a static capital adequacy rule and the banks' credit supply (Aiyar et al. 2014).

At the current juncture, experience and knowledge of the effectiveness of macroprudential instruments, and their calibration and interaction with each other and with monetary policy are still rather limited. Therefore, model simulations (such as agent-based modeling approaches) are necessary in order to study questions on the effectiveness of macroprudential tools and the interactions between macroprudential policy and monetary policy.

\section{Is a Macroprudential Policy a Solution for Crises?}

The recent financial turmoil made it clear that, notwithstanding that the pre-crisis financial market seemed to be functioning well, with diversified risks and robust institutional infrastructures, being individually safe and sound and properly supervised, systemic risks emerged, having remained undetected for a sufficiently long time to create the devastating collapse in financial markets worldwide. Policymakers have sought to rectify the financial catastrophe by imposing a broad set of financial regulations, both at the national and international levels. The promising innovation rising as a consequence of the crisis is the macroprudential policy. The core objectives of macroprudential policy, embodied in the Basel III regulatory framework (see BCBS 2011a), are to decrease the possibility and economic costs of possible systemic financial crises, to strengthen the resilience of the overall financial system, and to smooth the credit cycle (i.e., the fluctuations in asset prices, credit, and leverage). In other words, macroprudential policy targets crisis management.

Considering the many similarities in crisis run-ups, it may seem that it should be possible to predict and prevent crises. ${ }^{24}$ However, a crisis is still a possible "reality", and the "this-timeis-different" syndrome makes this difficult to do, as shown in the literature on financial crises (particularly see Claessens, Kose, Laeven \& Valencia 2014, Reinhart \& Rogoff 2009, Allen \& Gale 2009). At this point, are the chances of a system-wide view of financial regulation better in preventing future crises?

Being one of the main buzzwords materializing from the last financial turmoil, macroprudential policy gained followers and skeptics. In terms of the first group, macroprudential policy is a literally a "mindset", and they believe that it can manage economic cycles and constrain the financial instability inherent in financial markets and institutions. In the second group, there is

\footnotetext{
${ }^{24}$ One of main similarities is the presence of credit and asset price booms, fuelled by rapid debt accumulation. For more details see Claessens, Kose \& Terrones (2014), Reinhart \& Rogoff (2008).
} 
some skepticism about the possible effectiveness of macroprudential policy. The sources of this mistrust include the following: risks to financial stability are difficult to measure; the analytical framework for assessing transmission channels is underdeveloped; experience of the specific calibration of the instruments is lacking; institutional and political-economic considerations need to be looked at; and there are doubts as to whether all forms of financial frictions can even be addressed using macroprudential instruments (see Feroli et al. 2014, Goodhart 2014, Haldane \& Madouros 2012). This skepticism may be connected to an unwillingness to accept that series of regulatory measures stepping in the free functioning of financial markets became necessary to tame the excesses of finance. Accordingly, it is simply useless, because crises are never the same and political economies of booms are such that regulatory authorities will always find it difficult to smooth them.

It was clear from the beginning of macroprudential policy setup that the system-wide view of financial regulation is not just for a supervisory need, but also for the design of regulations. Both theoretically and empirically, it is recognized that the safety and soundness of individually taken financial institutions do not guarantee a stable and safe financial system. ${ }^{25}$ One of many obvious reasons is the various fallacies of composition.

With all the progress made, there is unfortunately still too much puzzlement around macroprudential policy, and little consensus on how to operationalize it. Partially, this is because its objective is defined very generally, but there is also little historical experience of using macroprudential tools and empirical evidence to asses their effectiveness and calibration. Furthermore, both theoretically and empirically, the measurement of financial (in)stability and systemic risk are hitherto in infancy, and there is no much coherence on the influence sphere and institutional setup for post-crisis macroprudential regulation. What are the strengths and limitations, advantages and disadvantages of the nowadays macroprudential regulatory framework? What is the boundary of financial regulation? Where are the systemic risks? How can one measure the systemic risk? How can lessons drown from the history of previous financial turmoils contribute to the crisis management abilities of macroprudential policy? What are the interactions schemes between ts between the monetary and macroprudential policies? These are questions that need answers.

From a macroprudential perspective, let us first note that, despite obvious progress in the literature analyzing the efficiency of macroprudential measures, the regulatory approach is still largely based on a widely criticized microprudential structure of supervision, which does not lean on "system-wide" characteristics of risks. Moreover, systemic risk (Haldane \& May 2011, Battiston et al. 2012b, Acemoglu et al. 2015) in modern financial systems arises endogenously out of interactions between the financial market participants, and cannot be captured only by individual financial institutions' balance sheets, especially when these metrics are static or backward looking. Hence the macroprudential approaches need to be more targeted and addressed, considering the interactions schemes across and between participants, markets, institutions, and across the different types of risks (e.g., market, credit, liquidity, and operational). Importantly, the heterogeneity of financial institutions and the difference in their degree of vulnerability and sensitivity to the same source of stress should be of specific importance for macroprudential ap-

\footnotetext{
${ }^{25}$ see Brunnermeier et al. (2009), Osinski et al. (2013) for a general discussion, and De Nicoló et al. (2012) for an analytical review of a macroprudential versus a microprudential perspective on financial stability and regulation.
} 
proach. Apart from missing a focus on systemic risks, many regulatory interventions fall behind for other reasons. Among those a scarcity of an appropriate analytical tools and data to be able to conduct the possible costs-benefit analysis of regulatory instruments. Furthermore, the data gap, the heterogeneity between the statistics of different countries, due to different definitions and methodologies in data aggregation, and the lack of internationally agreed-upon ontology on financial transactions (a single way of describing and reporting the financial contract) represents an "Achilles heel" of macroprudential policy making cross-border comparisons on efficiency of macroprudential instruments more difficult. In this sense shadow banking is of growing importance: the specific risks that emerge from these under-regulated or unregulated activities are very challenging for macroprudential policy implementation.

In the current form the post-crisis macroprudential policy and its efficiency can weakened due to regulatory arbitrages or possible cross-border leakages in regulation. The former president and CEO of the Federal Reserve Bank of Dallas, Richard W. Fisher, expressed his opinion on this as follows:

"[...] Macroprudential supervision is something of a Maginot Line: It can be circumvented. Relying upon it to prevent financial instability provides an artificial sense of confidence [...]” (Fisher 2014)

Approaches need to actively anticipate the side effects of one regulation or action on others, as well as the financial innovations both within and across jurisdictions to avoid "Goodhart's Law" situations (Goodhart et al. 1988). Macroprudential policy may leak owing to regulatory arbitrage. As already noted by O. Blanchard:

"[...]The reality of financial regulation is that new rules open new avenues for regulatory arbitrage, as institutions find loopholes in regulations. That in turn forces authorities to institute new regulations in an ongoing cat-and-mouse game (between a very adroit mouse and a less nimble cat). Staying away from dark corners will require continuous effort, not one-shot regulation[...]"(Blanchard 2014)

For instance, credit could be supplied throughout less capital-intensive channels, for instance via securitization. Macroprudential measures can give an incentive for "race to the bottom", according to which liquidity and capital may run out to the country with the lowest requirements. It is worth mentioning that shadow banking can play a central role in feeding such regulatory arbitrage. Moreover, metrics should foresee, anticipate and limit the probability if regulatory leakages between macroprudential policies. For example, a capital requirement directive under the EU jurisdiction imposes automatic reciprocity for countercyclical capital buffers up to $2.5 \%$. This means that if any of the EU countries introduces a countercyclical capital buffer to smooth the financial cycle in its economy, all other EU countries are bound by law to impose the same capital surcharge on banks' cross-border exposures to the country introducing the measure. This prevents the so-called negative in-ward spillovers, whereby branches of foreign banks increase lending to circumvent the restrictions set by the macroprudential authority on local banks. Without reciprocity, macroprudential policy is prone to leakages. Addressing those risks is challenging, for a number of reasons. Firstly, shadow banking is an elusive concept that is difficult to quantify using available statistics. Secondly, as I have argued, the tools needed to 
prevent the building-up of excessive risks in that sector are currently not in the set of instruments available to macroprudential authorities. Moreover, macroprudential policies could be weakened or strengthened by cross-border spillovers. Spillovers depend on the behavior of both borrowers and lenders following a macroprudential policy action. Positive spillovers reduce risks to financial stability, while negative spillovers raise these risks. For example, if a country (say, country A) raises capital requirements in response to excessive domestic credit growth, a neighboring country that also experiences excessive credit growth (say, country B) might benefit from this measure. If the financial markets are integrated, banks in country A will reduce their lending in country B, thus contributing to a slowdown in financial exuberance. However, if financial markets are segmented, or if financial cycles are not synchronized and country B is experiencing weak credit growth, the sign of the spillovers from the same macroprudential measure may turn from positive to negative. Negative spillovers clearly pose a threat to the effectiveness of macroprudential policy. For policymakers, it is therefore crucial to be aware of the possibility of such spillovers and their respective propagation channels, to coordinate policies to the best extent possible, and to apply mitigating measures to minimize leakages.

One of the most obvious fault lines in banking regulation, which was revealed after the European sovereign debt crisis, is the general application of zero-risk weights for sovereign exposures (Acharya et al. 2014). This deficiency comes from the way the global bank regulation standards have been applied in some countries, and especially in the EU. Combining a standardized approach of the Basel requirement and the Capital Requirement Directive (CDR) under EU jurisdiction, EU banks usually employ a zero-risk weight for sovereign debt and, thus, do not hold capital against any of the sovereign exposures to EU member states. ${ }^{26}$ Moreover, applying the LCR under Basel III, the European Commission treats all Member States bonds equally, irrespective of any external or internal ratings, thus incentivizing banks to hold sovereign debt and reinforce the sovereign-bank nexus.

In global capital framework of Basel III requirement non risk-based leverage requirement (that should be a backstop for risk-based capital requirement), in certain circumstances, can become the binding capital requirement for banks (i.e. a first stop), rather than the back stop measure, originally intended. A study commissioned by the Global Financial Markets Association and The Clearing House concludes that for more than half of the institutions analysed the leverage ratio of the proposed framework, rather than the all in Basel III risk-based capital requirements that include buffers and surcharges, would become the binding capital ratio. In particular, the prospect of a binding leverage ratio would effectively require much higher capital for banks least risky assets, such as cash. This would reduce the availability of lines of credit, thus constraining the pool of credit available to support economic growth (for more details see GFMA et al. 2013). At the same time there is some tension between the LCR and LR metrics: in non risk-based leverage requirement equating low-risk assets with riskier assets which produce a higher relative return than safer, low-risk assets, but also carry risk of higher exposure could discourage banks from holding assets such as cash and government bonds. At the same time, given that the LCR encourages banks to hold cash and government bonds as part of a liquid

\footnotetext{
${ }^{26}$ The European Banking Authority (EBA) stress test in 2011 reports that only 36 banks out of 91 participating European banks apply internal rating-based models (IRB) while computing risk-weighted assets. Thus, 55 banks have sovereign debt with zero-risk weight.
} 
assets, there is a tension with compliance with the LCR. This would be most relevant to those banks who would find the leverage ratio a greater hurdle to overcome compared to the risk-based capital requirements. Hence, without a system-wide view on both private and public provision of liquidity, a microprudential liquidity rule can act perversely, as when all banks have to meet a requirement at the same time. Therefore, reducing the risks of a crisis requires a system perspective combined with a macroprudential toolkit, some of which has to be global, given the close connections among financial systems and through international markets (and may have to involve capital flow management tools as well). Furthermore, it requires proper institutions to assure, besides system-wide risk monitoring, the necessary remedial actions.

\section{Concluding Remarks}

The global financial crisis has challenged the prevailing monetary policy paradigm, showing that low inflation rates and comparatively moderate business cycle fluctuations are not sufficient to ensure financial stability. As a result, a system-wide approach to financial regulation in terms of countercyclical macroprudential policy is required. Effective macroprudential policies (which include a range of constraints on leverage and the composition of balance sheets) could then contain risks ex-ante and help build buffers to absorb shocks ex-post. Experience and knowledge on the effectiveness of macroprudential policies, their calibrations, the interactions among financial distortions and macroprudential tools, and the interactions of those tools with monetary policy are still limited. The literature on the impact/effectiveness analysis of prudential policy tools and the ways in which they interact is developing rapidly, but is still in its infancy. Still, there have been valuable experiences in using macroprudential policy tools, especially in some of International Monetary Fund (IMF) studies (see Cerutti et al. 2015, Claessens et al. 2013, Zhang \& Zoli 2016) have shown the effectiveness of several tools, especially those related to credit conditions for obtaining mortgages or mortgage insurance and asset-based prudential tools. Furthermore, the theoretical literature reports substantial stabilizing gains from a countercyclical capital requirement rule introduced by the Basel III reform package (see Angelini et al. (2011), Agénor et al. (2013), Benes \& Kumhof (2015), Krug et al. (2015), Popoyan et al. (2015), among others).

Despite the relevant progress in empirical and theoretical literature and macroprudential design, unfortunately, the macroprudential policy framework is still largely based on a microprudential framework of regulations capturing individual institutions balance sheets. The present framework does not start from the system-wide characteristics of risks, and often misses key risks. Considering that empirical evidence on the effectiveness of macroprudential policy tools is still scarce, the use of macroprudential policy tools is likely to involve some experimentation and "learning-by-doing" practice.

Greater clarity is needed on the exact transmission and effectiveness of macroprudential instruments, including their interactions among themselves and with monetary policy. Although intermediate targets and tools of macroprudential and monetary policy differ, both types of policies have overlapping transmission mechanisms, because they work primarily through the financial system. One policy shapes the playing field of the other. The latter reflects the tensions 
that can be inherent in the simultaneous implementation of monetary and macroprudential policies. However, at the same time, the effects of one policy need to be considered in the conception and implementation of the other, owing to the same interconnectedness. Thus, they need to be coordinated, which is a non-trivial task, given that financial and business cycles could be de-synchronized.

While following the real-world developments, two obvious models stand out: macroprudential mandates are assigned (i) to a board, consisting of the relevant authorities, or (ii) to the central bank. Although the second model has a number of advantages in terms of accountability and expertise, there may be good reasons for creating a macroprudential board. Typically, financial stability is affected by different policy fields, and the identification of systemic risks may benefit from combining different fields of expertise, as long as the committee has a clear macroprudential focus. Nevertheless, the involvement of several authorities may complicate decision-making and weaken accountability, increasing the risk of inaction bias. Today's macroprudential policy has a high national concentration. This does not account for the possibility of macroprudential policy being weakened or strengthened because of cross-border spillovers. This argument is especially valid in the case of monetary unions.

With all the recent progress made, there is unfortunately still too much confusion around macroprudential policy concepts and little agreement on how to operationalize it. This is partially because of unclear objectives and a scarcity of experience in using macroprudential tools in order to gauge their effectiveness and calibration. Additional difficulties are that risks to financial stability are difficult to measure, the analytical framework for assessing transmission channels is underdeveloped, experience with the specific calibration of instruments is lacking, and institutional and political-economic considerations need to be examined. Moreover, the post-crisis macroprudential policy framework is still largely based on an outmoded and now largely repudiated conceptual framework of regulations, which does not start from system-wide characteristics of risks, and is still very much microprudential. Systemic risk in modern financial systems arises endogenously and cannot simply be captured using individual institutions' balance sheets or specific market or asset price-based measures alone, especially when these metrics are static or backward looking.

\section{Acknowledgements}

I am grateful for helpful comments and discussions by Andrea Roventini, John V. Duca, Peter Howitt, Domenico Delli Gatti and several participants at seminars and conferences where the paper has been presented and in particular FRAP 2014 (Oxford, UK), Finance and Economics Conference 2015, LUPCON (Frankfurt am Main, Germany). All usual disclaimers apply. This paper has been supported by European Union's Horizon 2020 grant: No. 640772 - Project Dolfins.

\section{References}

Acemoglu, D., Ozdaglar, A. \& Tahbaz-Salehi, A. (2015), 'Systemic risk and stability in financial networks', American Economic Review 105(2), 564-608.

Acharya, V., Engle, R. \& Pierret, D. (2014), 'Testing macroprudential stress tests: the risk of regulatory risk weights', Journal of Monetary Economics 65, 36-53. 
Adrian, T. \& Boyarchenko, N. (2012), 'Intermediary leverage cycles and financial stability', Becker Friedman Institute for Research in Economics Working Paper (2012-010).

Adrian, T. \& Liang, N. (2014), 'Monetary policy, financial conditions, and financial stability', FRB of New York Staff Report (690).

Agénor, P.-R., Alper, K. \& da Silva, L. P. (2013), 'Capital regulation, monetary policy and financial stability', International Journal of Central Banking 9(3), 193-238.

Ahuja, A. \& Nabar, M. (2011), 'Safeguarding banks and containing property booms: Cross-country evidence on macroprudential policies and lessons from hong kong sar', IMF Working Papers (11/284).

Aikman, D., Galesic, M., Gigerenzer, G., Kapadia, S., Katsikopoulos, K. V., Kothiyal, A., Murphy, E. \& Neumann, T. (2014), 'Taking uncertainty seriously: simplicity versus complexity in financial regulation', Bank of England Financial Stability Paper (28).

Aiyar, S., Calomiris, C. W. \& Wieladek, T. (2014), 'Does macro-prudential regulation leak? Evidence from a UK policy experiment', Journal of Money, Credit and Banking 46(s1), 181-214.

Alexander, C. \& Sheedy, E. (2008), 'Developing a stress testing framework based on market risk models', Journal of Banking \& Finance 32(10), 2220-2236.

Allen, F. \& Gale, D. (2000), 'Bubbles and crises', The economic journal 110(460), 236-255.

Allen, F. \& Gale, D. (2009), Understanding financial crises, Oxford University Press.

Alpanda, S., Cateau, G. \& Meh, C. (2014), 'A policy model to analyze macroprudential regulations and monetary policy', BIS Working Paper (461).

Altunbas, Y., Gambacorta, L. \& Marques-Ibanez, D. (2012), 'Do bank characteristics influence the effect of monetary policy on bank risk?', Economics Letters 117(1), 220-222.

Altunbas, Y., Gambacorta, L. \& Marques-Ibanez, D. (2014), 'Does monetary policy affect bank risk?', International Journal of Central Banking 10(1), 95-135.

Anand, K., Gai, P. \& Marsili, M. (2012), 'Rollover risk, network structure and systemic financial crises', Journal of Economic Dynamics and Control 36(8), 1088-1100.

Andersen, H. (2011), 'Procyclical implications of Basel II: can the cyclicality of capital requirements be contained?', Journal of Financial Stability 7(3), 138-154.

Angelini, P., Clerc, L., Cúrdia, V., Gambacorta, L., Gerali, A., Locarno, A., Motto, R., Roeger, W., Van den Heuvel, S. \& Vlček, J. (2014), 'Basel III: Long-term impact on economic performance and fluctuations', The Manchester School 83(2), 217-251.

Angelini, P., Neri, S. \& Panetta, F. (2011), 'Monetary and macroprudential policies', Bank of Italy Temi di Discussione (801).

Angeloni, I. \& Faia, E. (2013), 'Capital regulation and monetary policy with fragile banks', Journal of Monetary Economics 60(3), 311-324.

Arregui, N., Beneš, J., Krznar, I. \& Mitra, S. (2013), 'Evaluating the net benefits of macroprudential policy: a cookbook', IMF Working Paper (13/167).

Asea, P. K. \& Blomberg, B. (1998), 'Lending cycles', Journal of Econometrics 83(1), 89-128.

Ashraf, Q., Gershman, B. \& Howitt, P. (2011), 'Banks, market organization, and macroeconomic performance: an agent-based computational analysis', NBER Working Paper (17102).

Bailliu, J., Meh, C. \& Zhang, Y. (2012), 'Macroprudential rules and monetary policy when financial frictions matter', Bank of Canada Working Paper (6).

Balasubramanyan, L. \& VanHoose, D. D. (2013), 'Bank balance sheet dynamics under a regulatory liquiditycoverage-ratio constraint', Journal of Macroeconomics 37, 53-67.

Bank of England (2011), 'Instruments of macroprudential policy', Bank of England Discussion Paper 20.

Battiston, S., Gatti, D. D., Gallegati, M., Greenwald, B. \& Stiglitz, J. E. (2012a), 'Default cascades: When does risk diversification increase stability?', Journal of Financial Stability 8(3), 138-149. 
Battiston, S., Gatti, D. D., Gallegati, M., Greenwald, B. \& Stiglitz, J. E. (2012b), 'Liaisons dangereuses: Increasing connectivity, risk sharing, and systemic risk', Journal of Economic Dynamics and Control 36(8), 1121-1141.

BCBS (2011a), 'Basel III: A global regulatory framework for more resilient banks and banking systems', Basel Committee on Banking Supervision .

BCBS (2011b), 'Global systemically important banks: assessment methodology and the additional loss absorbency requirement', Bank for International Settlements Consultative Document.

BCBS (2012), 'Basel III: the net stable funding ratio', Bank for International Settlements .

BCBS (2013), 'The liquidity coverage ratio and liquidity risk monitoring tools', BIS .

Beau, D., Clerc, L. \& Mojon, B. (2012), 'Macro-prudential policy and the conduct of monetary policy', Banque de France Working Paper (390).

Behn, M., Detken, C., Peltonen, T. A. \& Schudel, W. (2013), 'Setting countercyclical capital buffers based on early warning models: would it work?'.

Behn, M., Haselmann, R. \& Wachtel, P. (2015), 'Procyclical capital regulation and lending', The Journal of Finance.

Benanke, B. \& Gertler, M. (1989), 'Agency costs, net worth, and business fluctuation', Americal Economic Review 1989, 14-31.

Benes, J. \& Kumhof, M. (2015), 'Risky bank lending and countercyclical capital buffers', Journal of Economic Dynamics and Control 58, 58-80.

Benigno, G., Chen, H., Otrok, C., Rebucci, A. \& Young, E. R. (2013), 'Financial crises and macro-prudential policies', Journal of International Economics 89(2), 453-470.

Bernanke, B. S. (2008), Reducing systemic risk, in 'Speech at the Federal Reserve Bank of Kansas Citys Annual Economic Symposium, Jackson Hole, Wyoming', Vol. 22.

Bernanke, B. S., Gertler, M. \& Gilchrist, S. (1999), 'The financial accelerator in a quantitative business cycle framework', Handbook of macroeconomics 1, 1341-1393.

Berndt, A. \& Gupta, A. (2009), 'Moral hazard and adverse selection in the originate-to-distribute model of bank credit', Journal of Monetary Economics 56(5), 725-743.

Bhattacharya, S. (1982), 'Aspects of monetary and banking theory and moral hazard', The Journal of Finance 37(2), 371-384.

Bianchi, J. (2014), 'Overborrowing and systemic externalities in the business cycle', American Economic Review 101(7), 3400-3426.

Bianchi, J. \& Mendoza, E. G. (2013), 'Optimal time-consistent macroprudential policy', NBER Working Paper (19704)

Bindseil, U. \& Lamoot, J. (2011), 'The Basel III framework for liquidity standards and monetary policy implementation', SFB 649 Discussion Paper (2011-041).

BIS (2010), 'Basel III: A global regulatory framework for more resilient banks and banking systems', Basel Committee on Banking Supervision, Basel .

BIS (2012), 'A framework for dealing with domestic systemically important banks', Bank for International Settlements, Consultative Document .

Blanchard, O. (2014), 'Where danger lurks', Finance \& Development 51(3), 28-31.

Blanchard, O., DellAriccia, G. \& Mauro, P. (2010), 'Rethinking macroeconomic policy', Journal of Money, Credit and Banking 42(s1), 199-215.

Blanchard, O. J., Dell'Ariccia, M. G. \& Mauro, M. P. (2013), 'Rethinking macro policy II: getting granular', IMF Staff Discussion Note (SDN/13/03).

Boissay, F., Collard, F. \& Smets, F. (2013), 'Booms and systemic banking crises', ECB Working Paper (1514). 
Borio, C., Drehmann, M. \& Tsatsaronis, K. (2014), 'Stress-testing macro stress testing: does it live up to expectations?', Journal of Financial Stability 12, 3-15.

Borio, C. E. \& Drehmann, M. (2009), 'Assessing the risk of banking crises-revisited', BIS Quarterly Review, March .

Borio, C. E. \& Lowe, P. W. (2004), 'Securing sustainable price stability: should credit come back from the wilderness?', BIS Working Paper (157).

Borio, C. \& Lowe, P. (2002), 'Assessing the risk of banking crises', BIS Quarterly Review pp. 43-54.

Borio, C. \& Zhu, H. (2012), 'Capital regulation, risk-taking and monetary policy: a missing link in the transmission mechanism?', Journal of Financial Stability 8(4), 236-251.

Bradford, G. \& Bagehot, W. (1874), 'Lombard street. a description of the money market'.

Bridges, J., Gregory, D., Nielsen, M., Pezzini, S., Radia, A. \& Spaltro, M. (2014), 'The impact of capital requirements on bank lending'.

Brinkhoff, J., Langfield, S., Mazzaferro, F., Salleo, C. \& Weeken, O. (2013), 'Risk management through the lens of macroprudential policy', Journal of Risk Management in Financial Institutions 6(2), 120-128.

Brunnermeier, M., Gorton, G. \& Krishnamurthy, A. (2014), 'Liquidity mismatch measurement', Risk Topography: Systemic Risk and Macro Modeling p. 99.

Brunnermeier, M. K., Crockett, A., Goodhart, C. A., Persaud, A. \& Shin, H. S. (2009), The fundamental principles of financial regulation, Vol. 11, Centre for Economic Policy Research.

Brunnermeier, M. K. \& Sannikov, Y. (2014a), 'International credit flows, pecuniary externalities, and capital controls', Princeton University Working Paper.

Brunnermeier, M. K. \& Sannikov, Y. (2014b), 'A macroeconomic model with a financial sector', American Economic Review 104(2), 379-421.

Bruno, V., Shim, I. \& Shin, H. S. (2015), 'Comparative assessment of macroprudential policies', BIS Working Paper (502).

Bruno, V. \& Shin, H. S. (2015), 'Capital flows and the risk-taking channel of monetary policy', Journal of Monetary Economics 71, 119-132.

Brzoza-Brzezina, M., Kolasa, M. \& Makarski, K. (2015), 'Macroprudential policy and imbalances in the euro area', Journal of International Money and Finance 51, 137-154.

Calomiris, C. W., Heider, F. \& Hoerova, M. (2014), 'A theory of bank liquidity requirements', Columbia Business School Research Paper (14-39).

Castro, C. \& Ferrari, S. (2014), 'Measuring and testing for the systemically important financial institutions', Journal of Empirical Finance 25, 1-14.

Cecchetti, S. G. \& Kohler, M. (2012), 'When capital adequacy and interest rate policy are substitutes (and when they are not)', BIS Working Paper (379).

Cerutti, E., Claessens, S. \& Laeven, M. L. (2015), 'The use and effectiveness of macroprudential policies: New evidence', IMF Working Paper (15-61).

Chadha, J. S. \& Corrado, L. (2012), 'Macro-prudential policy on liquidity: What does a DSGE model tell us?', Journal of Economics and Business 64(1), 37-62.

Challe, E., Mojon, B. \& Ragot, X. (2013), 'Equilibrium risk shifting and interest rate in an opaque financial system', European Economic Review 63, 117-133.

Christensen, I., Meh, C. \& Moran, K. (2011), 'Bank leverage regulation and macroeconomic dynamic', CIRANOScientific Publications 2011s-76.

Cincotti, S., Raberto, M. \& Teglio, A. (2012), 'Macroprudential policies in an agent-based artificial economy', Revue de l'OFCE 124(5), 205-234.

Claessens, S. (2014), 'An overview of macroprudential policy tools', IMF Working Paper (14/214). 
Claessens, S., Ghosh, S. R. \& Mihet, R. (2013), 'Macro-prudential policies to mitigate financial system vulnerabilities', Journal of International Money and Finance 39, 153-185.

Claessens, S., Kose, M. A. \& Terrones, M. E. (2014), 'The global financial crisis: How similar? How different? How costly?', Financial Crises: Causes, Consequences, and Policy Responses. Washington, DC: International Monetary Fund pp. 209-237.

Claessens, S., Kose, M. M. A., Laeven, M. L. \& Valencia, F. (2014), Financial Crises: Causes, Consequences, and Policy Responses, International Monetary Fund.

Colander, D. (2010), 'The economics profession, the financial crisis, and method', Journal of Economic Methodology 17(4), 419-427.

Committee on the Global Financial System (2012), 'Operationalising the selection and application of macroprudential instruments', CGFS Papers (48).

Cooke, J., Koch, C., Murphy, A. et al. (2015), 'Liquidity mismatch helps predict bank failure and distress', Economic Letter 10.

Covas, F. \& Fujita, S. (2010), 'Procyclicality of capital requirements in a general equilibrium model of liquidity dependence', International Journal of Central Banking 6(4), 137-173.

Crowe, C., DellAriccia, G., Igan, D. \& Rabanal, P. (2013), 'How to deal with real estate booms: lessons from country experiences', Journal of Financial Stability 9(3), 300-319.

Cussen, M., O’Brien, M., Onorante, L., O'Reilly, G. et al. (2015), 'Assessing the impact of macroprudential measures', Central Bank of Ireland Economic Letter series (3).

Da Silva, M. \& Lima, G. (2015), 'Combining monetary policy and prudential regulation: an agent-based modeling approach', Banco Central Do Brasil Working Papers (394).

Dawid, H., Harting, P. \& Neugart, M. (2014), 'Economic convergence: policy implications from a heterogeneous agent model', Journal of Economic Dynamics and Control 44, 54-80.

De Nicoló, M. G., Favara, G. \& Ratnovski, L. (2012), 'Externalities and macroprudential policy', IMF Staff Discussion Note (SDN/12/05).

Del Negro, M. \& Otrok, C. (2007), '99 Luftballons: Monetary policy and the house price boom across us states', Journal of Monetary Economics 54(7), 1962-1985.

Dell'Ariccia, G., Igan, D., Laeven, L., Tong, H., Bakker, B. \& Vandenbussche, J. (2012), 'Policies for macrofinancial stability: How to deal with credit booms', IMF Staff discussion note (SDN/12/06).

Dell'Ariccia, M. G., Laeven, M. L. \& Suarez, M. G. (2013), 'Bank leverage and monetary policy's risk-taking channel: Evidence from the United States', IMF Working Paper (13-143).

Delli Gatti, D., Di Guilmi, C., Gaffeo, E., Giulioni, G., Gallegati, M. \& Palestrini, A. (2005), 'A new approach to business fluctuations: heterogeneous interacting agents, scaling laws and financial fragility', Journal of Economic behavior \&f organization 56(4), 489-512.

Delli Gatti, D., Gallegati, M., Greenwald, B., Russo, A. \& Stiglitz, J. E. (2010), 'The financial accelerator in an evolving credit network', Journal of Economic Dynamics and Control 34(9), 1627-1650.

DellAriccia, G., Igan, D. \& Laeven, L. U. (2012), 'Credit booms and lending standards: Evidence from the subprime mortgage market', Journal of Money, Credit and Banking 44(2-3), 367-384.

Dosi, G. (2012), 'Economic coordination and dynamics: Some elements of an alternative 'evolutionary' paradigm', Economic Organization, Industrial Dynamics and Development, Selected Essays 2.

Dosi, G., Fagiolo, G., Napoletano, M. \& Roventini, A. (2013), 'Income distribution, credit and fiscal policies in an agent-based keynesian model', Journal of Economic Dynamics and Control 37(8), 1598-1625.

Dosi, G., Fagiolo, G., Napoletano, M., Roventini, A. \& Treibich, T. (2015), 'Fiscal and monetary policies in complex evolving economies', Journal of Economic Dynamics and Control 52, 166-189.

Dosi, G., Fagiolo, G. \& Roventini, A. (2010), 'Schumpeter meeting keynes: a policy-friendly model of endogenous growth and business cycles', Journal of Economic Dynamics and Control 34(9), 1748-1767. 
Drehmann, M. \& Juselius, M. (2014), 'Evaluating early warning indicators of banking crises: Satisfying policy requirements', International Journal of Forecasting 30(3), 759-780.

Duca, J. V. \& Ling, D. C. (2015), 'The other (commercial) real estate boom and bust: the effects of risk premia and regulatory capital arbitrage', Available at SSRN 2663194.

Duca, J. V., Muellbauer, J. \& Murphy, A. (2010), 'Housing markets and the financial crisis of 2007-2009: lessons for the future', Journal of Financial Stability 6(4), 203-217.

Duca, M. L. \& Peltonen, T. A. (2013), 'Assessing systemic risks and predicting systemic events', Journal of Banking \& Finance 37(7), 2183-2195.

ECB (2014), 'The ESRB handbook on operationalising macro-prudential policy in the banking sector'.

ECB Heads of Research (2014), Report on the macro-prudential research network (MARS), European Central Bank.

Fagiolo, G. \& Roventini, A. (2012), 'Macroeconomic policy in DSGE and agent-based models', Revue de l'OFCE (5), 67-116.

Fagiolo, G. \& Roventini, A. (2016), 'Macroeconomic policy in DSGE and agent-based models redux: New developments and challenges ahead', Laboratory of Economics and Management (LEM) Working Paper Series $(2016 / 17)$.

Farhi, E. \& Tirole, J. (2012), 'Collective moral hazard, maturity mismatch and systemic bailouts', American Economic Review 101(1), 60-93.

Fatás, A., Kannan, P., Rabanal, P. \& Scott, A. (2009), 'Lessons for monetary policy from asset price fluctuations', International Monetary Fund (Chapter 3 of the October 2009 World Economic Outlook).

Feroli, M., Kashyap, A. K., Schoenholtz, K. L. \& Shin, H. S. (2014), 'Market tantrums and monetary policy', Chicago Booth Research Paper (14-09).

Fisher, R. W. (2014), 'Monetary policy and the maginot line', Remarks at the University of Southern California 16.

Freixas, X., Laeven, L. \& Peydro, J.-L. (2015), Systemic risk, crises and macroprudential policy, MIT Press.

FSB (2011a), 'Macroprudential policy tools and frameworks: Update for G20 finance ministers and central bank governors'.

FSB (2011b), 'Policy measures to address systemically important financial institutions'.

FSB (2014), 'Adequacy of loss-absorbing capacity of global systemically important banks in resolution', Financial Stability Board Consultative Document 10.

Gaffard, J.-L. \& Napoletano, M. (2012), 'Agent-based models and economic policy', Revue de l'OFCE. Debates and Policies 124.

Gai, P., Haldane, A. \& Kapadia, S. (2011), 'Complexity, concentration and contagion', Journal of Monetary Economics 58(5), 453-470.

Galati, G. \& Moessner, R. (2014), 'What do we know about the effects of macroprudential policy?', De Nederlandsche Bank Working Paper (440).

Gan, J. (2004), 'Banking market structure and financial stability: Evidence from the Texas real estate crisis in the 1980s', Journal of Financial Economics 73(3), 567-601.

Geanakoplos, J. (2014), 'Leverage, default, and forgiveness: Lessons from the American and European crises', Journal of Macroeconomics 39, 313-333.

Geanakoplos, J., Axtell, R., Farmer, D. J., Howitt, P., Conlee, B., Goldstein, J., Hendrey, M., Palmer, N. M. \& Yang, C. Y. (2012), 'Getting at systemic risk via an agent-based model of the housing market', The American Economic Review 102(3), 53-58.

GFMA, ABA, FSR, IIB, IIF \& ISDA (2013), 'Comments in response to the consultative document on the revised Basel III leverage ratio framework and disclosure requirements'. 
Goodhart, C. (2014), 'Lessons for monetary policy from the euro-area crisis', Journal of Macroeconomics 39, 378382.

Goodhart, C., Tsomocos, D. P. \& Vardoulakis, A. P. (2009), Foreclosures, monetary policy and financial stability, in 'Materials of Conference Proceedings of the 10th International Academic Conference on Economic and Social Development'.

Goodhart, C. et al. (1988), 'The evolution of central banks', MIT Press Books 1.

Guerini, M., Napoletano, M. \& Roventini, A. (2016), 'No man is an island: The impact of heterogeneity and local interactions on macroeconomic dynamics', Laboratory of Economics and Management (LEM) Working Paper Series $(2016 / 24)$.

Guzman, J. P. M. \& Roldos, M. J. (2014), 'Monetary and macroprudential policies to manage capital flows', IMF Working Paper (14/30).

Hahm, J.-H., Mishkin, F. S., Shin, H. S. \& Shin, K. (2012), 'Macroprudential policies in open emerging economies', NBER Working Paper (17780).

Haldane, A. G. \& Madouros, V. (2012), 'The dog and the frisbee', Revista de Economía Institucional 14(27), 1356.

Haldane, A. G. \& May, R. M. (2011), 'Systemic risk in banking ecosystems', Nature 469(7330), 351-355.

Hartlage, A. W. (2012), 'The Basel III liquidity coverage ratio and financial stability', Michigan Law Review 111(3).

He, Z. \& Krishnamurthy, A. (2014), 'A macroeconomic framework for quantifying systemic risk', NBER Working Paper (19885).

Hoogduin, L. H. (2010), 'Macroprudential instruments and frameworks: a stocktaking of issues and experiences', BIS Working Paper (38).

Howitt, P. (2011), 'What have central bankers learned from modern macroeconomic theory?', Journal of Macroeconomics 34, 11-22.

Igan, D. \& Kang, H. (2011), 'Do loan-to-value and debt-to-income limits work? Evidence from Korea', IMF Working Paper (11/297).

IMF (2011), 'Macro prudential policy: An organizing framework', IMF 14.

IMF (2013), The Interaction of Monetary and Macroprudential Policies, International Monetary Fund.

Ioannidou, V., Ongena, S. \& Peydró, J. L. (2009), 'Monetary policy and subprime lending: a tall tale of low federal funds rates, hazardous loans and reduced loan spreads', European banking centre discussion paper 45.

Jiménez, G., Ongena, S., Peydró, J.-L. \& Saurina, J. (2014), 'Hazardous times for monetary policy: What do twenty-three million bank loans say about the effects of monetary policy on credit risk-taking?', Econometrica 82(2), 463-505.

Jiménez, G., Ongena, S., Peydró, J.-L. \& Saurina Salas, J. (2012), 'Macroprudential policy, countercyclical bank capital buffers and credit supply: Evidence from the Spanish dynamic provisioning experiments', National Bank of Belgium Working Paper (231).

Jónsson, Á. (2009), Why Iceland?: How One of the World's Smallest Countries Became the Meltdown's Biggest Casualty, McGraw-Hill.

Jordà, Ò., Schularick, M. \& Taylor, A. M. (2015), 'Leveraged bubbles', NBER Working Paper (21486).

Kannan, P., Rabanal, P. \& Scott, A. M. (2012), 'Monetary and macroprudential policy rules in a model with house price booms', The BE Journal of Macroeconomics 12(1).

Kato, R., Kobayashi, S. \& Saita, Y. (2010), 'Calibrating the level of capital: the way we see it', Bank of Japan Working Paper Series (10-E-6).

King, M. R. (2013), 'The Basel III net stable funding ratio and bank net interest margins', Journal of Banking $\mathcal{E}$ Finance 37(11), 4144-4156. 
Kiyotaki, N. \& Moore, J. (1997), 'Credit cycles', The Journal of Political Economy 105(2), 211-248.

Kohn, D. (2010), 'Macroprudential instruments and frameworks: a stocktaking of issues and experiences', Committee on the Global Financial System Papers (38).

Koo, R. C. (2011), The Holy Grail of Macroeconomics: Lessons from JapanÂs Great Recession, John Wiley \& Sons.

Krug, S. (2015), 'The interaction between monetary and macroprudential policy: Should central banks "lean against the wind" to foster macrofinancial stability?', Economics Working Paper, Christian-AlbrechtsUniversität Kiel, Department of Economics (2015-08).

Krug, S., Lengnick, M. \& Wohltmann, H.-W. (2015), 'The impact of Basel III on financial (in) stability: An agent-based credit network approach', Quantitative Finance pp. 1-16.

Kuttner, K. N. \& Shim, I. (2013), 'Can non-interest rate policies stabilize housing markets? evidence from a panel of 57 economies', NBER Working Paper (19723).

Lambertini, L., Mendicino, C. \& Punzi, M. T. (2013), 'Leaning against boom-bust cycles in credit and housing prices', Journal of Economic Dynamics and Control 37(8), 1500-1522.

Landier, A., Sraer, D. A. \& Thesmar, D. (2011), The risk-shifting hypothesis: Evidence from subprime originations., in 'AFA 2012 Chicago Meetings Paper'.

LeBaron, B. \& Tesfatsion, L. (2008), 'Modeling macroeconomies as open-ended dynamic systems of interacting agents', American Economic Review 98, 246-250.

Leeper, E. M. \& Nason, J. M. (2014), 'Bringing financial stability into monetary policy', CAEPR Working Paper (2014-003)

Lengnick, M., Krug, S. \& Wohltmann, H.-W. (2013), 'Money creation and financial instability: An agent-based credit network approach', Economics 7(32), 1.

Lim, C. H., Costa, A., Columba, F., Kongsamut, P., Otani, A., Saiyid, M., Wezel, T. \& Wu, X. (2011), 'Macroprudential policy: what instruments and how to use them? lessons from country experiences', IMF working papers pp. $1-85$.

Lim, C. H., Krznar, I., Lipinsky, F., Otani, A. \& Wu, X. (2013), 'The macroprudential framework: policy responsiveness and institutional arrangements', IMF Working Paper (13/166).

Maddaloni, A. \& Peydro, J.-L. (2013), 'Monetary policy, macroprudential policy and banking stability: evidence from the euro area', ECB Working Paper (1560).

Mahapatra, B. (2012), Underlying concepts and principles of dynamic provisioning, in 'Keynote address at the Conference on Introduction of dynamic provisioning framework for banks in India, organised by the Centre for Advanced Financial Research and Learning (CAFRAL) Mumbai', Vol. 21.

McDonald, C. (2015), 'When is macroprudential policy effective?', BIS Working Paper (496).

Merrouche, O. \& Nier, E. (2010), 'What caused the global financial crisis', IMF Working Paper (10/265).

Miles, D., Yang, J. \& Marcheggiano, G. (2013), 'Optimal bank capital', The Economic Journal 123(567), 1-37.

Napoletano, M., Roventini, A. \& Gaffard, J. L. (2015), 'Time-varying fiscal multipliers in an agent-based model with credit rationing', Laboratory of Economics and Management (LEM) Working Paper Series (19).

Nier, E. W. \& Merrouche, O. (2010), 'What caused the global financial crisis? evidence on the drivers of financial imbalances 1999-2007', IMF Working Paper (10/265).

Osinski, J., Seal, K. \& Hoogduin, M. L. (2013), 'Macroprudential and microprudential policies: toward cohabitation', IMF Working Paper (13/15).

Ozkan, F. G. \& Unsal, D. F. (2014), 'On the use of monetary and macroprudential policies for small open economies', IMF Working Paper (14/112).

Pariès, M. D., Sørensen, C. K., Rodriguez-Palenzuela, D. et al. (2011), 'Macroeconomic propagation under different regulatory regimes: Evidence from an estimated DSGE model for the euro area', International Journal of Central Banking 7(4), 49-113. 
Popoyan, L., Napoletano, M. \& Roventini, A. (2015), 'Taming macroeconomic instability: Monetary and macro prudential policy interactions in an agent-based model', Laboratory of Economics and Management (LEM) Working Paper Series (2015/33).

Purnanandam, A. (2011), 'Originate-to-distribute model and the subprime mortgage crisis', Review of Financial Studies 24(6), 1881-1915.

Quint, D. \& Rabanal, P. (2014), 'Monetary and macroprudential policy in an estimated DSGE model of the euro area', International Journal of Central Banking 10(2), 169-236.

Raberto, M., Teglio, A. \& Cincotti, S. (2012), 'Debt, deleveraging and business cycles: an agent-based perspective', Economics: The Open-Access, Open-Assessment E-Journal 6(2012-27), 1-49.

Reinhart, C. M. \& Rogoff, K. (2009), This time is different: eight centuries of financial folly, Princeton University Press.

Reinhart, C. M. \& Rogoff, K. S. (2008), 'Is the 2007 us sub-prime financial crisis so different? an international historical comparison', NBER Working Paper (13761).

Repullo, R. \& Suarez, J. (2013), 'The procyclical effects of bank capital regulation', Review of Financial Studies 26(2), 452-490.

Riccetti, L., Russo, A. \& Gallegati, M. (2013), 'Leveraged network-based financial accelerator', Journal of Economic Dynamics and Control 37(8), 1626-1640.

Sarlin, P. (2014), 'Mapping financial stability. computational risk management series'.

Sarlin, P. \& Peltonen, T. A. (2013), 'Mapping the state of financial stability', Journal of International Financial Markets, Institutions and Money 26, 46-76.

Saurina, J. (2009), 'Dynamic provisioning', World Bank, Washington, DC .

Schmitz, S. W. (2013), 'The impact of the liquidity coverage ratio (LCR) on the implementation of monetary policy', Economic Notes 42(2), 135-170.

Sengupta, R. (2010), 'Alt-a: The forgotten segment of the mortgage market', Federal Reserve Bank of St. Louis Review 92 (January/February 2010).

Seppecher, P. \& Salle, I. (2015), 'Deleveraging crises and deep recessions: a behavioural approach', Applied Economics 47(34-35), 3771-3790.

Shim, I., Bogdanova, B., Shek, J. \& Subelyte, A. (2013), 'Database for policy actions on housing markets', BIS Quarterly Review .

Shin, H. S. (2005), 'Financial system liquidity, asset prices and monetary policy', The Changing Nature of the Business Cycle,'Reserve Bank of Australia pp. 312-335.

Shin, H. S. (2015), 'Macroprudential tools, their limits and their connection with monetary policy', Panel remarks at IMF Spring Meeting event: Rethinking macro policy III: progress or confusion? 15 April 2015, Washington, $D C$.

Smets, F. (2013), 'Financial stability and monetary policy: How closely interlinked?', Sveriges Riksbank Economic Review 3, 121-160.

Stiglitz, J. E. (2011), 'Rethinking macroeconomics: What failed, and how to repair it', Journal of the European Economic Association 9(4), 591-645.

Suh, H. (2012), 'Macroprudential policy: its effects and relationship to monetary policy', FRB of Philadelphia Working Paper (12-28).

Suh, H. (2014), 'Dichotomy between macroprudential policy and monetary policy on credit and inflation', Economics Letters 122(2), 144-149.

Tabak, B. M., Fazio, D. M. \& Cajueiro, D. O. (2013), 'Systemically important banks and financial stability: The case of Latin America', Journal of Banking \& Finance 37(10), 3855-3866.

Taylor, A. M. (2015), 'Credit, financial stability, and the macroeconomy', NBER Working Paper (21039). 
Teglio, A., Raberto, M. \& Cincotti, S. (2012), 'The impact of banks' capital adequacy regulation on the economic system: An agent-based approach', Advances in Complex Systems 15(supp02), 1250040.

Tesfatsion, L. \& Judd, K. L. (2006), 'Handbook of computational economics: agent-based computational economics', 2.

Tinbergen, J. (1952), 'On the theory of economic policy', Contributions to Economic Analysis 1.

Unsal, D. F. (2011), 'Capital flows and financial stability: monetary policy and macroprudential responses', IMF Working Paper (11/189).

Valencia, F. (2014), 'Monetary policy, bank leverage, and financial stability', Journal of Economic Dynamics and Control 47, 20-38.

van den End, J. W. \& Kruidhof, M. (2013), 'Modelling the liquidity ratio as macroprudential instrument', Journal of Banking Regulation 14(2), 91-106.

van den End, J. W. \& Tabbae, M. (2012), 'When liquidity risk becomes a systemic issue: Empirical evidence of bank behaviour', Journal of Financial Stability 8(2), 107-120.

van der Hoog, S. (2015), 'The limits to credit growth: Mitigation policies and macroprudential regulations to foster macrofinancial stability and sustainable debt', Working Papers in Economics and Management (08-2015).

van der Hoog, S. \& Dawid, H. (2015), 'Bubbles, crashes and the financial cycle: Insights from a stock-flow consistent agent-based macroeconomic model', Bielefeld Working Papers in Economics and Management (012015).

Vandenbussche, J., Vogel, U. \& Detragiache, E. (2015), 'Macroprudential policies and housing prices: A new database and empirical evidence for Central, Eastern, and Southeastern Europe', Journal of Money, Credit and Banking 47(S1), 343-377.

Wezel, T., Chan-Lau, J. A. \& Columba, F. (2012), 'Dynamic loan loss provisioning: simulations on effectiveness and guide to implementation', IMF Working Paper (12/110).

Wong, T.-c., Fong, T., Li, K.-f. \& Choi, H. (2011), 'Loan-to-value ratio as a macroprudential tool-Hong Kong's experience and cross-country evidence', Systemic Risk, Basel III, Financial Stability and Regulation .

Yellen, J. L. (2011), 'Macroprudential supervision and monetary policy in the post-crisis world', Business Economics 46(1), 3-12.

Zhang, L. \& Zoli, E. (2016), 'Leaning against the wind: macroprudential policy in asia', Journal of Asian Economics 42, 33-52.

Zilberman, R. \& Tayler, W. (2014), 'Financial shocks, loan loss provisions and macroeconomic stability', Lancaster University Working Paper (023). 